\title{
PERTUMBUHAN KREDIT OPTIMAL
}

\author{
G.A Diah Utari, Trinil Arimurti, Ina Nurmalia Kurniati'
}

\begin{abstract}
Banking credit has an important role in financing the national economy and as engine of economic growth. The high growth of credit is a commonly normal phenomenon as a positive consequence from the increase of financial deepening in economy. On the other hand, one must consider the implication of credit growth towards the financial stabilization and macro condition. Therefore, the policy authority should be able to identify the credit growth that is considered to be risky for the financial system and the macro stability. This research measures the credit growth without negative impact towards the economy and the banking condition. The testing uses Markov Switching (MS) Univariate approach and MS Vector Error Correction Model. The result with MS Univariate approach shows that the upper limit of the real credit growth in moderate regime is about 17.39 percent, while using the MS VECM approach is about 22.15 percent.
\end{abstract}

Keywords: bank, credit, risk, markov switching error correction model

JEL classification: G21, E51, C23,C24

1 Adalah peneliti ekonomi di Group Riset Ekonomi (BRE) Bank Indonesia.Pandangan dalam tulisan ini semata-mata merupakan pandangan penulis dan bukan merupakan pandangan Bank Indonesia. Ucapan terima kasih ditujukan kepada Kepala GRE Bpk. Iskandar Simorangkir, Bpk. Sugiarso Safuan, Bpk. Reza Anglingkusumo dan seluruh peneliti di Departemen Riset Ekonomi dan Kebijakan Moneter lainnya, serta Wiweko Junianto yang membantu proses pengumpulan data. Penulis dapat dihubungi di utari@bi.go.id, trinil@bi.go.id dan inanurmalia@bi.go.id. 


\section{PENDAHULUAN}

Kredit perbankan memiliki peran penting dalam pembiayaan perekonomian nasional dan merupakan motor penggerak pertumbuhan ekonomi. Ketersediaan kredit memungkinkan rumah tangga untuk melakukan konsumsi yang lebih baik dan memungkinkan perusahaan untuk melakukan investasi yang tidak bisa dilakukan dengan dana sendiri. Selain itu dengan permasalahan moral hazard dan adverse selection yang umum terjadi, bank memainkan peran penting dalam mengalokasikan kapital dan melakukan pemantauan untuk memastikan bahwa dana masyarakat disalurkan pada kegiatan yang memberikan benefit optimal. Terlepas dari mulai meningkatnya peran pembiayaan melalui pasar modal, pembiayaan melalui perusahaan keuangan yang meliputi bank dan lembaga pembiayaan, kredit perbankan masih mendominasi total kredit kepada sektor swasta dengan rata-rata sebesar $85 \%^{2}$.

Setelah mengalami penurunan yang cukup signifikan selama periode 2009 hingga kuartal pertama 2010 akibat krisis keuangan global, pertumbuhan kredit kembali meningkat. Pada akhir 2011 pertumbuhan kredit secara nominal dan riil masing-masing tercatat sebesar 24,7\% dan 20,1\%, melampaui pertumbuhan di 2010 yang sebesar 23,3\% dan 15,3\% (Grafik 1). Hingga Maret 2012, pertumbuhan kredit nominal adalah 25\% sementara pertumbuhan kredit riil adalah 20\%. Pangsa kredit terhadap PDB pada akhir 2011 juga tercatat sebesar 30\%, meningkat cukup signifikan dibandingkan posisi 2010 yang sebesar 27\% (Grafik 2). Kredit perbankan diperkirakan akan terus tumbuh di tengah penurunan suku bunga BI rate.
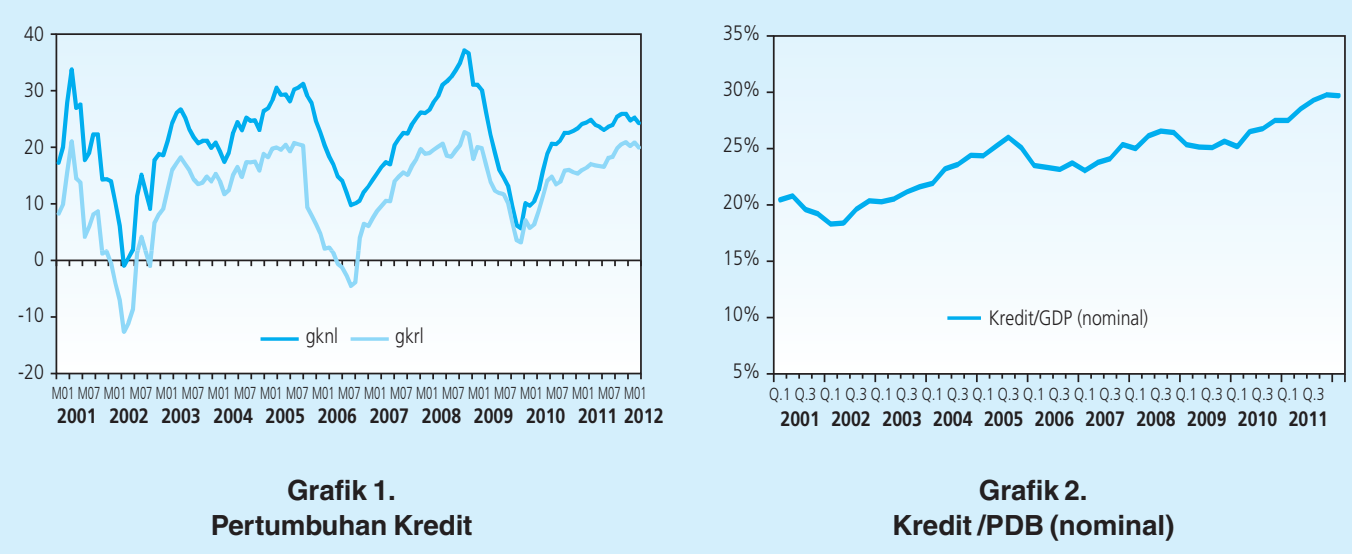

Pertumbuhan kredit yang cukup tinggi dipengaruhi oleh kondisi perekonomian yang kondusif sepanjang 2011. Hubungan kausalitas yang positif antara pertumbuhan ekonomi dan kredit mencerminkan adanya hubungan prosiklikal antara kedua variabel tersebut. Hasil

2 Rata-rata pemberian kredit oleh bank kepada sektor swasta dibandingkan dengan total kredit kepada sektor swasta yang mencakup kredit oleh perbankan, perusahaan leasing, factoring, consumer financing dan pegadaian sejak 1990 s.d 2010. 
ini sesuai dengan beberapa studi empiris yang menunjukkan bahwa pertumbuhan ekonomi mendorong pertumbuhan kredit dengan elastisitas lebih dari satu dalam jangka panjang (Terrones and Mendoza, 2004)3. Dalam kasus Indonesia, hubungan kausalitas yang terjadi lebih mengarah pada peran pertumbuhan ekonomi yang lebih dominan sebagai lead dari pertumbuhan kredit dibandingkan kondisi sebaliknya (Nugroho dan Prasmuko (2010) \& Utari dkk (2011)). Tingginya pertumbuhan kredit di satu sisi dapat dipandang normal dan merupakan konsekuensi positif dari meningkatnya financial deepening dalam perekonomian. Namun demikian pada saat yang bersamaan juga timbul pemikiran mengenai implikasi dari pertumbuhan kredit ini terhadap stabilitas keuangan dan kondisi makro terutama ketika pertumbuhan kredit yang cepat juga diiringi dengan melemahnya current account dan kerentanan sektor keuangan. Pertanyaan selanjutnya adalah sampai tingkat berapakah, pertumbuhan kredit dapat dianggap kondusif bagi pertumbuhan dan tidak menimbulkan tekanan terhadap inflasi dan kondisi mikro perbankan? Assesment pertumbuhan kredit tidak hanya menyangkut pada besaran leve/ tetapi juga pada sektor apa kredit tersebut disalurkan.

Berdasarkan beberapa literatur, pertumbuhan kredit yang berlebihan dapat mengancam kestabilan ekonomi makro. Peningkatan kredit khususnya kredit konsumsi dapat memicu pertumbuhan permintaan aggregat diatas output potensial yang mengakibatkan perekonomian memanas. Pada gilirannya akan berdampak kepada peningkatan inflasi, defisit current account serta apresiasi nilai tukar riil. Pada saat yang bersamaan, selama periode ekspansi institusi perbankan cenderung memiliki ekspektasi yang terlalu optimis pada kemampuan membayar nasabah dan akibatnya kurang hati-hati dalam memberikan kredit kepada golongan beresiko tinggi. Sebagai akibatnya terjadi penumpukan pinjaman yang berpotensi menjadi bad loans pada periode ekonomi kontraksi.

Pelajaran yang didapat dari krisis keuangan global belakangan ini adalah pentingnya otoritas kebijakan mewaspadai risiko dari penyaluran kredit yang berlebihan. Hal ini mengingat periode pertumbuhan kredit agregat yang berlebihan kerap terkoneksi dengan risiko sistemik. Oleh karenanya otoritas kebijakan disarankan dapat mengidentifikasi pada saat mana pertumbuhan kredit sudah dianggap berpotensi menimbulkan risiko bagi kestabilan sistem keuangan dan kestabilan makro. Hal lain yang tidak kalah pentingnya adalah rancangan kebijakan makroprudensial yang bersifat countercyclical untuk mengantisipasi risiko dari pertumbuhan kredit yang berlebihan. Menjaga stabilitas sistem keuangan khususnya perbankan dalam konteks ini tidak hanya memastikan bahwa sektor perbankan baik secara keseluruhan maupun individual memiliki solvencyyang cukup pada saat disstress, tetapi juga memiliki modal yang cukup untuk menjaga aliran kredit dalam perekonomian.

Dengan berdasarkan pertimbangan diatas, tujuan penelitian ini adalah menghitung tingkat pertumbuhan kredit yang diperkirakan tidak berdampak negatif terhadap perekonomian dan

3 Literatur lainnya menemukan hal yang sebaliknya dimana kredit mendorong pertumbuhan ekonomi diantaranya adalah penelitian oleh Beck, Levine and Loayza (2000) dan Rajan \& Zingales (2001). 
kondisi perbankan. Bagian kedua dari paper ini menyajikan teori untuk memberikan kerangka analisis. Bagian ketiga mengulas metodologi dan data yang digunakan, sementara hasil estimasi dan analisis disajikan pada bagian keempat. Kesimpulan dan rekomendasi kebijakan akan diberikan pada bagian kelima dan menjadi bagian penutup.

\section{TEORI}

\subsection{Pertumbuhan Kredit, Stabilitas Sistem Keuangan \& Stabilitas Makro}

Episode dimana terjadi pertumbuhan kredit yang sangat tinggi atau sering disebut juga dengan "credit boom" dapat memicu terjadinya dilema kebijakan. Credit boom didefinisikan sebagai: 1) periode dimana terjadi deviasi yang cukup ekstrim dari pertumbuhan kredit terhadap pola historis jangka panjangnya yang tidak didukung oleh fundamental yang selaras (losifov \& Khamis, 2009) dan 2) suatu episode dimana pertumbuhan kredit kepada sektor swasta melebihi pertumbuhan yang terjadi semasa siklus bisnis yang normal (Mendoza \& Terrones, 2008). Di satu sisi, kredit yang makin tinggi akan meningkatkan akses kepada sektor keuangan dan dapat mendukung pertumbuhan investasi dan perekonomian. Namun di sisi lain kondisi ini dapat mengarah pada kerentanan sektor keuangan melalui penurunan standar pemberian pinjaman, leverage yang berlebihan serta inflasi harga asset (Reinhart dan Rogoff , 2009.)

Kredit perbankan dapat tumbuh dengan cepat dipicu oleh beberapa faktor (Dell'Ariccia, et all, 2012) yaitu : 1) bagian dari fase normal suatu siklus bisnis ,2) adanya liberalisasi di sektor keuangan dan 3) aliran modal masuk yang tinggi. Sebagaimana dijelaskan dalam Dell Ariccia (2012), dalam kondisi normal, sejalan dengan meningkatnya perekonomian domestik, umumnya kredit akan tumbuh lebih cepat. Hal ini dipicu oleh kebutuhan untuk investasi perusahaan baik dalam bentuk investasi baru maupun penambahan kapasitas. Tingginya pertumbuhan kredit juga dapat dipicu oleh liberalisasi di sektor keuangan yang umumnya memang dirancang untuk meningkatkan kedalaman sektor keuangan. Faktor lain yang turut berkontribusi terhadap peningkatan kredit adalah adanya aliran modal masuk. Aliran modal masuk akan meningkatkan penawaran dana oleh perbankan yang pada akhirnya meningkatkan pertumbuhan kredit. Berbeda dengan tiga yang pertama, pertumbuhan kredit yang dipicu oleh respon yang berlebihan pelaku sektor keuangan lebih mengarah pada pertumbuhan kredit yang berlebihan (credit boom). Kondisi ini didasari teori financial accelerator ${ }^{4}$. Financial accelerator terjadi karena adanya market imperfection akibat asimetric information sertalemahnya kelembagaan. Selain tiga faktor diatas, Terrones (2011) juga mengemukakan faktor lainnya yaitu respon yang berlebihan dari pelaku sektor keuangan karena adanya perubahan risiko dari waktu ke waktu.

Pertumbuhan kredit yang berlebihan berdasarkan beberapa literatur kerap kali dikaitkan sebagai faktor kunci yang berkontribusi terhadap krisis di sektor keuangan khususnya di negara

4 Financial accelerator adalah suatu mekanisme dimana perkembangan sektor keuangan dapat mempengaruhi siklus bisnis (Fischer, 1933 dalam Penetta \& Angelini, 2009). 
emerging. Krisis perbankan besar dalam 30 tahun terakhir yang terjadi di Chili (1982), Denmark, Finland, Norwegia dan Swedia pada 1990/91, Mexico (1994) serta Thailand dan Indonesia (1997/98) juga didahului oleh periode credit boom ( Dell Aricia, et all, 2012). Kaminsky, Lizondo dan Reinhart (1997) menemukan bahwa lima dari tujuh studi yang disurvey membuktikan pertumbuhan kredit merupakan salah satu determinan dari krisis keuangan dan atau krisis perbankan. Craig et all (2006) serta Hardy dan Pazarbasiouglu (1998) dalam Craig et all (2006) menemukan bahwa penurunan siklus usaha (business cycle) dan krisis di emerging market umumnya didahului dengan periode pertumbuhan kredit yang tinggi serta penggelembungan harga aset. Hasil yang sama juga diperoleh dari penelitian Goldstein (2001), IMF (2004a) dan Mendoza \& Terrones (2008). Goldstein (2001) membuktikan adanya keterkaitan antara credit boom dan peluang terjadinya krisis kembar (krisis keuangan dan krisis perbankan). IMF menemukan bahwa tiga per empat dari periode credit boom di negara-negara emerging yang menjadi sampel berhubungan dengan krisis perbankan dan tujuh per delapan berhubungan dengan krisis keuangan. Sementara itu Mendoza \& Terrones (2008) menemukan bahwa 68\% dari boom kredit di negara emerging berhubungan dengan krisis keuangan, 55\% dengan krisis perbankan dan $32 \%$ dengan sudden stops.

Peningkatan pertumbuhan kredit yang signifikan umumnya akan meningkatkan kerentanan sistem keuangan. Kondisi ini didorong oleh perilaku perbankan yang cenderung prosiklikal. Karakteristik prosiklikal sektor perbankan melalui penyaluran kredit merupakan elemen risiko sistemik yang perlu diperhitungkan dengan seksama oleh otoritas pengambil kebijakan. Oleh karenanya salah satu tujuan dari kebijakan makroprudensial adalah membuat insentif bagi sektor keuangan untuk berlaku less-procyclically ( Gersl dan Jakubic 2010 dalam Frait et all, 2011).

Sebagaimana terlihat pada Grafik 3 yang dieksplorasi pada paper Frait et all, (2011), pada fase ekspansi, ekspansi aggregat demand meningkat signifikan yang juga meningkatkan pertumbuhan lending perbankan serta leverage perekonomian. Kondisi ini umumnya dibarengi dengan peningkatan profit perusahaan, harga asset dan ekspektasi konsumen. Peningkatan harga asset akan meningkatkan penilaian agunan (kolateral) sehingga pinjaman baru akan lebih mudah diberikan dan mendorong bank serta nasabah untuk lebih berani mengambil risiko. Pada fase ekspansi ini terjadi akumulasi risiko yang akan termaterialisasi ketika kondisi ekonomi menurun. Meningkatnya leverage / indebtedness rumah tangga dan perusahaan akan meningkatkan kerentanan terhadap risiko makro-ekonomi melalui pertumbuhan aggregat demand yang melampaui kapasitas perekonomian dan akhirnya menimbulkan tekanan overheating. Pinjaman perbankan mendorong peningkatan konsumsi dan import dengan efek lanjutannya adalah meningkatnya current account deficit. Memburuknya current account deficityang berkelanjutan pada gilirannya dapat memicu berkurangnya aliran modal masuk dan akhirnya mempengaruhi kondisi kesehatan sektor keuangan dan perbankan. Hal ini dikarenakan pasar bereaksi terhadap peningkatan risiko kondisi makro melalui penyesuaian portfolio investment termasuk kepemilikan mata uang. 
Sementara itu dari sisi mikro, stock utang yang lebih tinggi membuat debitur terekspose pada risiko suku bunga dan nilai tukar (jika kredit diberikan dalam valas). Bila eksposur ini tidak di-hedging maka kerentanan debitor terhadap kedua risiko diatas, akan meningkatkan risiko kredit. Peningkatanpembayaran utang akibat peningkatan suku bunga atau depresiasi mata uang dapat menimbulkan implikasi yang serius terhadap portfolio pinjaman bank dan atau aktivitas perekonomian riil. Anggaran rumah tangga dan perusahaan akan banyak digunakan untuk mengakomodir meningkatnya beban pembayaran utang. Setelah puncak dari siklus boom berakhir, profit perusahaan menurun sehingga kelayakan kredit (creditworthiness) pun menurun. Kondisi ini berpotensi meningkatkan non performing loans yang pada akhirnya mempengaruhi kesehatan neraca bank.

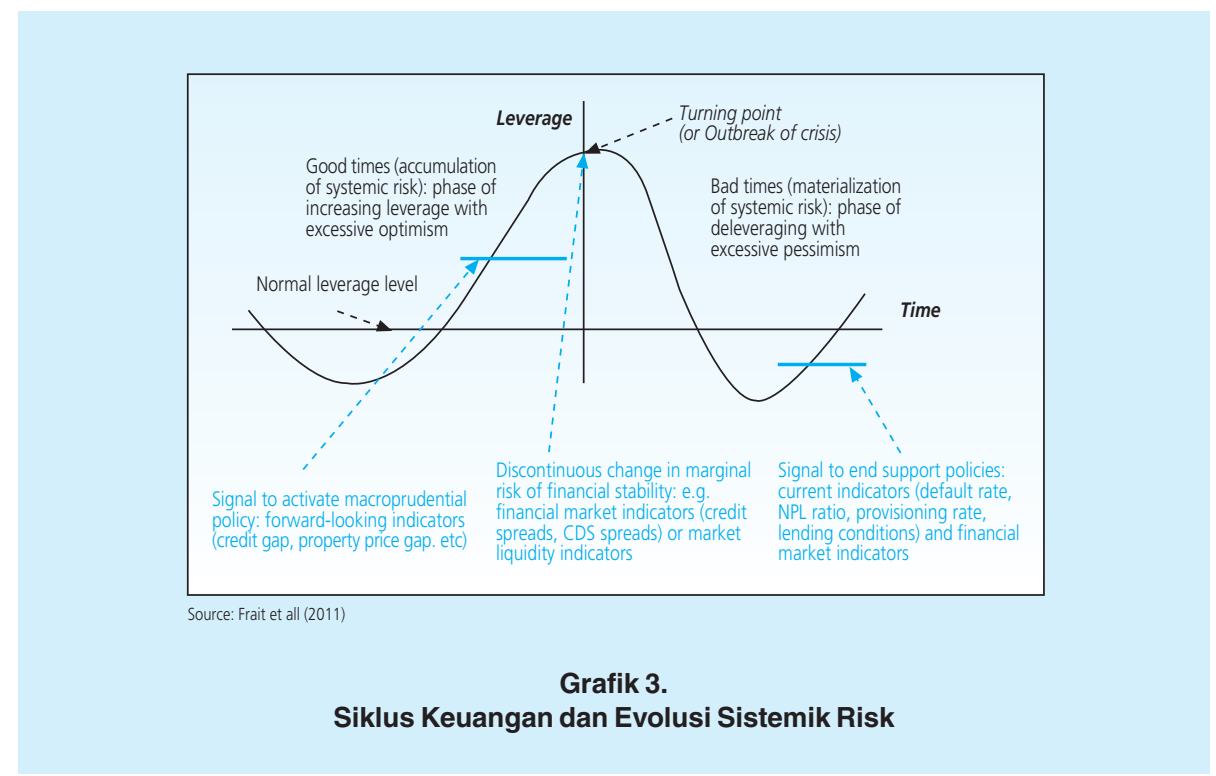

Kerentanan neraca perbankan, sistem keuangan dan makroekonomi memiliki kaitan yang erat. Ketidakseimbangan kondisi makro yang tercermin dari perubahan mendadak suku bunga dan nilai tukar dapat mempengaruhi kemampuan membayar utang debitur dan pada saat yang bersamaan meningkatkan kekhawatiran terhadap kondisi kesehatan sektor keuangan. Sebagai contoh, sudden revearsal capital inflow dapat mendorong terjadinya hard landing di perekonomian dan memaksa otoritas untuk meningkatkan suku bunga. Kondisi ini selanjutnya akan menimbulkan tekanan pada sektor perbankan melalui credit risk yang berasal dari peningkatan suku bunga, perlambatan ekonomi dan penurunan nilai kolateral. Di lain pihak kekhawatiran terhadap kondisi sektor keuangan akan mendorong ketidakstabilan kondisi makro akibat reaksi pasar. 


\subsection{Identifikasi Excessive Credit}

Salah satu cara untuk mengidentifikasi adanya pertumbuhan kredit yang berlebihan adalah menggunakan perbandingan pertumbuhan kredit dalam satu kelompok tingkat perekonomian. Rasio kredit per PDB banyak digunakan sebagai variabel pembanding karena PDB mencerminkan kemampuan membayar kembali. Oleh karenanya negara dengan tingkat perekonomian yang sama seharusnya memiliki tingkat keseimbangan kredit yang sama. Negara dengan tingkat perekonomian yang rendah sewajarnya akan memiliki tingkat kredit yang lebih rendah dibandingkan negara lebih maju. Sehingga dengan melihat trend dari rasio kredit per PDB pada negara dengan tingkat perekonomian yang sama dapat diidentifikasi berapa threshold kredit di kelompok negara tersebut.

Pendekatan lain yang digunakan untuk mengidentifikasi adanya pertumbuhan kredit yang berlebih adalah metode HP Filter. Trend yang diestimasi dari HP Filter dipandang sebagai equilibrium dan kredit boom didefinisikan sebagai kredit yang melebihi threshold tertentu disekitar trend. Threshold dapat ditentukan sebagai nilai deviasi relatif dari trendnya seperti yang digunakan Gourinchas et al. (2001) dan IMF (2004). Nakornthab et al. (2003) melakukan analisa terhadap komponen trend dari rasio kredit terhadap PDB dengan periode estimasi 1951-2002. Kritik utama terhadap metode HP filter yang menggunakan besaran kredit semata adalah tidak diperhitungkannya faktor fundamental perekonomian yang mempengaruhi keseimbangan stok pinjaman.

Estimasi equilibrium kredit menggunakan variabel-variabel fundamental perekonomian merupakan pendekatan yang paling sering digunakan. Hofmann (2001) melakukan estimasi tingkat equilibrium dari rasio kredit terhadap PDB dengan model VECM. Boyssay et al. (2005) mengaplikasikan model ECM dan panel data kredit negara-negara Eropa Tengah dan Timur. Backe et al (2005) melakukan estimasi dengan model panel ECM pada kombinasi beberapa negara OECD dan negara-negara emerging. Eller et al (2010) menggunakan VECM dan mengestimasi persamaan jangka panjang yang merupakan sisi permintaan dari kredit dan persamaan jangka pendek yang merupakan sisi penawaran kredit. Dinamika jangka pendek dimodelkan dengan markov switching error correction yang memungkinkan koefisien kredit bervariasi sesuai dengan rejimnya. Egert et al (2006) dalam Kelly et al (2011) menggunakan metode panel out-of-sample untuk mengestimasi tingkat keseimbangan kredit di negara-negara dengan perekonomian transisi.

\section{METODOLOGI}

Dalam paper ini, analisa excessive kredit dilakukan dengan menggunakan pendekatan HP Filter.Selain itu juga digunakan pendekatan keseimbangan pasar kredit dengan menggunakan variabel fundamental dengan Markov Switching Vector Error Correction Model (MSVECM). Kedua pendekatan ini merupakan metode yang bertumpu pada informasi di masa lalu. 


\subsection{Analisa HP Filter}

HP filter diperkenalkan oleh Hodrick dan Prescott (1980), merupakan metode detrending yang flexible dan umum digunakan dalam riset ekonomi.

Dimisalkan suatu data series $y_{t}$ dapat dipisahkan menjadi 2 komponen yaitu trend $\left(g_{t}\right)$ dan siklus $\left(c_{t}\right)$ dan dituliskan sebagai $y_{t}=g_{t}+c_{t}$. Metode HP Filter memisahkan komponen siklus dengan menyelesaikan persamaan optimalisasi dari loss function berikut yang juga dikenal dengan pendekatan HP filter dua sisi:

$$
\min _{\left\{g_{t}\right\}_{t=1}^{T}} \sum_{t=1}^{T}\left(y_{t}-g_{t}\right)^{2}+\lambda \sum_{t=1}^{T}\left(g_{t+1}-2 g_{t}+g_{t-1}\right)^{2}
$$

dimana $\lambda$ (lambda) adalah parameter penghalus (smoothing parameter). Suku pertama dari persamaan (1) mengukur keakuratan model, atau dengan kata lain merupakan penalti untuk varians dari komponen siklikal. Sementara suku kedua adalah penalti dari tingkat kehalusan pada trend. Oleh karenanya terdapat konflik antara tingkat kehalusan trend dengan goodness of fit-nya dan parameter $\lambda$ merupakan parameter "trade off" yang dapat diatur untuk permasalahan tersebut. Jika $\lambda$ bernilai nol maka komponen trend sama dengan data asli $\left(g_{t}=\right.$ $\left.y_{t}\right)$, sedangkan jika mendekati tak hingga $(\lambda \rightarrow \infty)$, maka trend akan konvergen menjadi trend linier $\left(g_{t}=b * t\right)$.

Hodrick dan Prescott menyarankan $\lambda=1600$ untuk data kuartalan yang menjadi standar untuk analisa siklus bisnis. Nilai $\lambda$ ini mengasumsikan siklus bisnis memiliki frekuensi sekitar 7.5 tahun. Ravn and Uhlig (2002) dari Drehman \& Borio et all (2010) menunjukkan bahwa nilai $\lambda$ juga harus disesuaikan jika frekuensi data berubah. Konvensi peneliti mengusulkan nilai $\lambda=100$ untuk data tahunan, $\lambda=1600$ untuk data quartalan, dan $\lambda=14400$.

Tidak dapat dipungkiri, metode HP Filter ini juga memiliki beberapa kelemahan seperti yang dikemukakan oleh Cottarelli et al. (2005) yaitu: 1) HP Filter mengukur trend dari keseluruhan observasi dan mengabaikan kemungkinan adanya structural break, 2) HP Filter cukup sensitif dengan bias titik ujung. Jika titik awal atau titik akhir dari data tidak merefleksikan hal yang sama pada siklusnya maka kemungkinan terjadinya bias keatas/kebawah, 3) HP Filter sensitif terhadap pemilihan durasi waktu. Gourichas et al (2001) melakukan rolling HP Filter dan menemukan bahwa hasil estimasi HP Filter dapat sangat berbeda dengan ex-post trend estimation dan 4) HP Filter sensitif terhadap parameter penghalus ( $\lambda$ ) yang digunakan.

Pada kajian ini, excessive credit growth akan dianalisa dengan melihat deviasi dari trend jangka panjang (yang dilakukan dengan metode HP Filter) terhadap pertumbuhan kredit baik total maupun agregasinya serta rasio Kredit terhadap PDB dan melihat deviasi dari tren jangka panjangnya. Penggunaan rasio Kredit terhadap PDB mengikuti pendekatan yang diusulkan oleh Basel Committee on Banking Supervision (2010). Tingkat threshold yang digunakan adalah 1 kali dan 1.75 kali (mengikuti IMF (2004)) standar deviasi dari trend jangka panjangnya. 


\begin{tabular}{|c|c|c|c|c|}
\hline \multicolumn{5}{|c|}{$\begin{array}{c}\text { Tabel } 1 . \\
\text { Data untuk Pengujian dengan HP Filter }\end{array}$} \\
\hline & Data Aggregat & Sumber Data & Frekuensi & Periode Observasi \\
\hline- & Pertumbuhan Kredit Riil* & DSM-BI & Bulanan & Jan 2001-Dec 2011 \\
\hline- & Rasio Kredit/ PDB Nominal & DSM-BI & Triwulanan & Q1.2001-Q4 2011 \\
\hline
\end{tabular}

\subsection{MSVAR}

Model Markov Switching (MS) dari Hamilton (1989) yang juga dikenal dengan model regime switching merupakan salah satu model time series non linier yang populer. Model ini mengandung beberapa struktur (persamaan) yang dapat menggambarkan karakteristik data time series pada rejim yang berbeda. Dengan melakukan switching antar struktur, model ini diharapkan dapat menangkap dinamika yang lebih kompleks. Fitur utama dari MS adalah mekanisme switching yang dikendalikan oleh unobservable state variable yang mengikuti rantai markov orde 1. Secara umum sifat umum dari markov adalah mengatur bahwa nilai sekarang terpengaruh oleh nilai masa lalu. MS dapat menjelaskan data yang terkorelasi yang menunjukkan pola dinamis pada beberapa periode waktu. Model MS telah banyak diaplikasikan untuk menganalisa data time series ekonomi dan keuangan.

Model MS-VAR menyediakan kerangka kerja untuk analisa representasi multivariat (dan univariat) dengan adanya perubahan rejim. Model MS-VAR adalah model struktur dinamis yang bergantung dengan nilai dari state variabel $\left(S_{t}\right)$ yang mengontrol mekanisme switching antara beberapa state (rejim). Bentuk umum model MS-VAR adalah :

$$
y_{t}=v\left(s_{t}\right)+A_{1}\left(s_{t}\right) y_{t-1}+\cdots+A_{p}\left(s_{t}\right) y_{t-p}+\varepsilon_{t}
$$

di mana $Y_{t}=\left(y_{11}, \ldots, y_{n t}\right)$ adalah vektor runtun waktu berdimensi $\mathrm{n}, \mathrm{v}$ adalah vektor dari berbagai intersep, $A_{1}, \ldots, A_{p}$ adalah matriks yang mengandung parameter autoregressive, dan $\varepsilon_{\mathrm{t}}$ adalah random error.

Pada persamaan (2) suku pertama di sebelah kanan, $v\left(S_{t}\right)$, diasumsikan bervariasi sesuai state-nya. Spesifikasi switching yang menggunakan intersep digunakan pada kasus di mana transisi terhadap mean dari state lainnya diasumsikan mengikuti lintasan yang halus. Representasi alternatif dapat digunakan jika mean diasumsikan berubah-ubah atau bervariasi mengikuti state-nya. Spesifikasi tersebut bermanfaat pada kasus-kasus dimana terdapat lompatan nilai mean setelah terjadi perubahan rejim.

Dalam Krolzig (1997) dilustrasikan untuk Markov Switching 2 Rejim dengan AR 1 yang terjadi switching pada mean dan volatilitasnya sbb: 
$y_{t}=\mu_{S_{t}}+A\left(y_{t-1}-\mu_{S_{t-1}}\right)+u_{t} \sim N I D\left(0, \sigma_{S_{t}}^{2}\right)$

di mana $\mu_{S_{t}}=\mu_{0}\left(1-S_{t}\right)+\mu_{1} S_{t} \operatorname{dan} \sigma_{S_{t}}^{2}=\sigma_{0}^{2}\left(1-S_{t}\right)+\sigma_{1}^{2} S_{t}$

Pada setiap spesifikasi MS diasumsikan bahwa rejim unobserved St mengikuti proses markov berderajat satu. Implikasinya rejim saat ini St bergantung pada rejim satu periode sebelumnya St-1. Probabilitas transisi dari rejim St-1 ke St dapat dinotasikan dengan

$$
P\left(S_{t}=j \mid S_{t-1}=i\right)=p i j
$$

Di mana $p_{i j}$ adalah probabilitas statei diikuti oleh statejdengan $P_{i i}+P_{i j}=1$ dan $0<p_{i j}<1$. Notasi dalam bentuk matriks transisi P adalah sbb.

$$
\left(\begin{array}{l}
P\left(S_{t}=i\right) \\
P\left(S_{t}=j\right)
\end{array}\right)=\left(\begin{array}{ll}
p_{i i} & p_{j i} \\
p_{i j} & p_{j j}
\end{array}\right)\left(\begin{array}{l}
P\left(S_{t-1}=i\right) \\
P\left(S_{t-1}=j\right)
\end{array}\right)
$$

Estimasi dari probabilitas transisi $p_{i j}$ umumnya diselesaikan secara numerik dengan Maximum Likelihood Estimator.

Conditional probability density function pada observasi $y_{t}$ dengan state variabel $S_{t}, S_{t-1}$ dan observasi sebelumnya yakni

$$
\begin{aligned}
& F_{t-1}=\left\{y_{t-1}, y_{t-2}, \ldots\right\}=f\left(y_{t} \mid S_{t}, S_{t-1}, F_{t-1}\right) \\
& =\frac{1}{\sqrt{2 \pi \sigma_{S_{t}}^{2}}} \exp \left(-\frac{\left[y_{t}-\mu_{S_{t}}-A\left(y_{t-1}-\mu_{S_{t-1}}\right)\right]^{2}}{2 \sigma_{S_{t}}^{2}}\right)
\end{aligned}
$$

Dan karena $u_{t}=y_{t}-\mu_{S_{t}}-A\left(y_{t-1}-\mu_{S_{t-1}}\right) \sim N I D\left(0, \sigma_{S_{t}}^{2}\right)$.

Aturan rantai untuk conditional probabilities ${ }^{5}$ berlaku sehingga

$$
f\left(y_{t}, S_{t}, S_{t-1} \mid F_{t-1}\right)=f\left(y_{t} \mid S_{t}, S_{t-1}, F_{t-1}\right) P\left(S_{t}, S_{t-1} \mid F_{t-1}\right)
$$

Sedemikian sehingga fungsi log-likelihood yang dioptimalisasikan adalah

$$
l(\theta)=\sum_{t=1}^{T} l_{t}(\theta)
$$

di mana

$$
l_{t}(\theta)=\log \left(\sum_{S_{t}=0}^{1} \sum_{S_{t-1}=0}^{1} f\left(y_{t} \mid S_{t}, S_{t-1}, F_{t-1}\right) P\left(S_{t}, S_{t-1} \mid F_{t-1}\right)\right)
$$




$$
\theta=\left(p_{00}, p_{11}, A, \mu_{0}, \mu_{1}, \sigma_{0}^{2}, \sigma_{1}^{2}\right)
$$

Aturan rantai dipergunakan untuk memperoleh conditional joint probability $P\left(S_{t}, S_{t-1} \mid F_{t-1}\right)$.

$$
P\left(S_{t}, S_{t-1} \mid F_{t-1}\right)=P\left(S_{t} \mid S_{t-1}, F_{t-1}\right) P\left(S_{t-1} \mid F_{t-1}\right)
$$

Dan karena sifat markov $P\left(S_{t} \mid S_{t-1}, F_{t-1}\right)=P\left(S_{t} \mid S_{t-1}\right)$ maka

$$
P\left(S_{t}, S_{t-1} \mid F_{t-1}\right)=P\left(S_{t} \mid S_{t-1}\right) P\left(S_{t-1} \mid F_{t-1}\right)
$$

Jika joint probability pada saat $\mathrm{t}$ sudah diketahui maka likelihood $\mathrm{t}(\theta)$ dapat dihitung. Maximum Likelihood Estimates untuk $\theta$ diperoleh dari iterasi memaksimumkan fungsi likelihood dimana pada masing-masing iterasi fungsi likelihood nya diperbaharui.

Misal $P\left(S_{0}=1 \mid F_{0}\right)=P\left(S_{0}=1\right)=\pi$ diketahui sedemikian sehingga $P\left(S_{0}=0\right) 1=\pi$. Maka probabilitas $P\left(S_{t}, \mid F_{t-1}\right)$ dan joint probability $P\left(S_{t}, S_{t-1} \mid F_{t-1}\right)$ dapat ditentukan dengan menjalankan algoritma berikut:

1. Diketahui $P\left(S_{t-1}=i \mid F_{t-1}\right), i=0,1$, pada saat $t$

$$
P\left(S_{t}=j, S_{t-1}=i \mid F_{t-1}\right)=P\left(S_{t}=j \mid S_{t-1}=i\right) P\left(S_{t-1}=i \mid F_{t-1}\right)
$$

2. Ketika $y_{t}$ diketahui, maka informasi $F_{t}=\left\{F_{t-1}, y_{t}\right\}$ dapat diperbaharui sehingga probabilitasnya dapat dihitung dengan

$$
\begin{array}{r}
P\left(S_{t}=j, S_{t-1}=i \mid F_{t}\right)=P\left(S_{t}=j, S_{t-1}=i\right) P\left(S_{t-1}=i \mid F_{t-1}\right) \\
=\frac{f\left(y_{t}\left|S_{t}=i, S_{t-1}=j, y_{t}\right| F_{t-1}\right)}{f\left(y_{t} \mid F_{t-1}\right)} \\
=\frac{f\left(y_{t} \mid S_{t}=j, S_{t-1}=i, F_{t-1}\right) P\left(S_{t}=j, S_{t-1}=i \mid F_{t-1}\right)}{\sum_{S_{t-1}=0}^{1} f\left(y_{t} \mid S_{t}, S_{t-1}, F_{t-1}\right) P\left(S_{t}=s t, S_{t-1}=s t-1 \mid F_{t-1}\right)} \\
P\left(S_{t}=s t \mid F_{t}\right)=\sum_{S_{t-1}=0}^{1} P\left(S_{t}=s t, S_{t-1}=s t-1 \mid F_{t-1}\right)
\end{array}
$$

Probabilitas Steady state adalah $P\left(S_{0}=1, \mid F_{0}\right)$ dan $P\left(S_{0}=0, \mid F_{0}\right)$

Yakni $P\left(S_{0}=1, \mid F_{0}\right)=\frac{1-p 00}{2-p 00-p 11}$ dan $P\left(S_{0}=0, \mid F_{0}\right)=\frac{1-p 11}{2-p 00-p 11}$.

Data yang digunakan pada analisa ini adalah data kredit riil bulanan periode Januari 2003 hingga Maret 2012. Periode ini dipilih untuk menghilangkan dampak adanya krisis asia. Sumber data adalah Bank Indonesia. 


\subsection{MS VECM}

Dalam penelitian ini juga akan dilakukan uji empiris untuk melihat threshold kredit dengan analisis multivariat yang memperhitungkan variabel demand dan supply kredit. Dari hasil pengujian empiris ini juga akan dilakukan analisis untuk melihat faktor yang mempengaruhi perubahan kredit dalam jangka panjang dan jangka pendek.

Analisa MSVECM terdiri atas 2 tahap analisa yakni Model Vector Error Correction (VECM) dilanjutkan dengan analisa Markov Switching. VECM adalah model VAR yang dirancang untuk digunakan pada data series yang tidak stasioner dan diketahui memiliki hubungan kointegrasi. Dalam VECM terdapat spesifikasi hubungan kointegrasi yang membatasi perilaku jangka panjang dari variabel endogen dan eksogen agar konvergen terhadap hubungan kointegrasinya namun memungkinkan adanya penyesuaian dinamis dalam jangka pendek. Dalam kointegrasi dikenal istilah error correction karena deviasi terhadap keseimbangan jangka panjang secara bertahap dikoreksi melalui penyesuaian jangka pendek. MS-VECM adalah VECM dimana pada beberapa parameternya dilakukan shifting. Sesuai Krolzig (1997) VECM untuk variabel I(1) dapat dimodelkan menjadi

$$
\Delta x_{t}=v\left(s_{t}\right)+\alpha\left(s_{t}\right)\left(\beta x_{t-1}\right)+\sum_{i=1}^{k-1} \Gamma_{i}\left(\Delta x_{t-i}\right)+u_{t}
$$

Dengan $\Delta x_{t}$ adalah vektor dari variabel yang berdimensi $m, v\left(s_{t}\right)=$ adalah rejim dependen dengan intercept, $\Gamma_{i}$ adalah matriks parameter dan varian error diperkenankan untuk berubah sepanjang rejim $u_{t} \sim\left(0, \Sigma\left(s_{t}\right)\right)$. Dalam kaitan ini $\alpha\left(s_{t}\right)$ adalah matriks penyesuaian parameter dan $\beta$ adalah matrik dari parameter jangka panjang (vektor kointegrasi).

Tahapan yang dilakukan pada analisa VECM dapat ditampilkan dalam bagan berikut

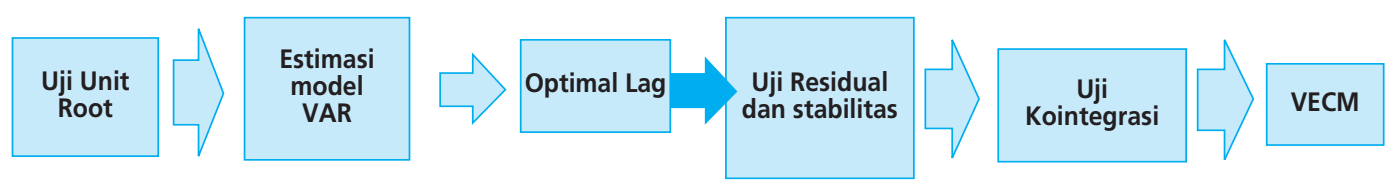

Sebelum uji kointegrasi, perlu dilakukan beberapa uji pendahuluan. Pertama, uji lag optimal yang dilakukan untuk mengatasi masalah autokorelasi dan heteroskedastisitas (Gujarati, 2003). Penentuan lag optimal menjadi penting karena lag yang terlalu panjang akan membuang derajat kebebasan, sementara lag yang terlalu pendek akan menghasilkan spesifikasi model yang salah (Gujarati, 2003). Penentuan lag berdasarkan lima kriteria, yaitu sequential modified LR test statistic, Akaike Information Criterion (AIC), Schwarz Information Criterion (SC), Final Prediction Error (FPE), dan Hannan-Quin Information (HQ). Dari kriteria tersebut, penelitian ini akan menggunakan kriteria yang memberikan lag terpendek. Selanjutnya dilakukan uji residual dalam bentuk correlogram. Sistem persamaan VAR dikatakan lolos uji autokorelasi jika korelasi antar variabel dengan lag yang dipilih berada dalam rentang yang ditetapkan. 
Setelah melakukan berbagai uji pendahuluan, maka uji kointegrasi dapat dilakukan. Apabila ditemukan vektor kointegrasi, selanjutnya dilakukan uji weak exogeneity untuk memastikan adanya hubungan kausalitas jangka panjang dan untuk memeriksa apakah terdapat feedback dari variabel jangka pendek ke variabel dependen. Pengujian weak exogeneity masingmasing variabel dilakukan dengan merestriksi $\alpha_{i}=0$, di mana $\alpha$ merupakan vektor koefisien adjustment dan $\mathrm{i}=1,2,3$. Jika restriksi nol tidak ditolak, artinya variabel tersebut tidak memiliki feedback ke deviasi masa lalu dari hubungan jangka panjangnya (weakly exogenous).

Sementara itu, adanya hubungan kointegrasi bukan berarti terjadi ekuilibrium dalam model. Kointegrasi mampu menangkap hubungan jangka panjang antara variabel dependen dan variabel penjelasnya, namun tidak mampu menangkap bagaimana respons dinamis variabel dependen akibat perubahan yang terjadi di variabel penjelasnya. Untuk menangkap respons tersebut, dilakukan uji dalam kerangka koreksi erroryaitu Vector Error Correction Model (VECM). Model jangka pendek yang mengandung error correction term ini memperlihatkan bagaimana mekanisme penyesuaian untuk kembali ke kondisi ekuilibrium ketika variabel dependen terganggu oleh shock eksogen. Setelah melakukan uji kointegrasi dan weak exogeneity, dilakukan estimasi VECM berdasarkan persamaan berikut:

$$
\Delta x_{t}=\mu_{0}+\sum_{i=1}^{k-1} \Gamma_{i} \Delta x_{t-1}+\delta E C T_{t-1}+e_{t}
$$

di mana ECT merupakan error correction term yang diperoleh dari vektor kointegrasi; $\delta$ koefisien koreksi erroryang menunjukkan respons variabel dependen di setiap periode $t$. Dengan kata lain, $\delta$ menunjukkan speed of adjustment untuk kembali ke ekuilibrium dan harus bertanda negatif signifikan dan tidak lebih besar dari satu. Apabila terjadi disekuilibrium, nilai negatif tersebut menunjukkan proses koreksi error yang terjadi. Sementara itu, nilai $\delta$ yang rendah mendekati nol berarti efek dinamis mendominasi perilaku pertumbuhan kredit dalam jangka pendek. Sebaliknya, jika $\delta$ bernilai lebih besar mendekati satu berarti efek jangka panjangnya mendominasi perilaku pertumbuhan kredit dalam jangka pendek, artinya dinamika jangka pendek berpengaruh kecil terhadap pertumbuhan kredit.

Berdasarkan hasil estimasi VECM linier, analisis dilanjutkan untuk mengestimasi MS-VECM untuk melihat hubungan antara variabel yang mempengaruhi permintaan kredit dengan kredit.

\section{Persamaan Jangka Panjang Kredit: Hubungan Kointegrasi}

Untuk menganalisa perubahan perilaku kredit yang optimal bagi perekonomian secara makro maupun mikro perbankan kami mengadopsi model yang diusulkan oleh Psaradakis et al (2004) dan digunakan pula oleh Eller et al (2010). Kerangka pikir yang digunakan untuk analisa ini adalah : (i) kredit memiliki hubungan jangka panjang dengan variabel-variabel fundamental makroekonomi (demand for credit) dan dalam jangka pendek dipengaruhi oleh variabel mikro perbankan (supply for credit), (ii) adjustment dari volume kredit pada ekuilibriumnya mungkin 
saja tidak linier karena terdapat periode dimana pasar kredit berada di titik disekuilibrium dan atau faktor-faktor yang mempengaruhi kredit dapat berubah seiring waktu

Persamaan demand for credit yang digunakan pada penelitian ini mengacu pada model Eller et al (2010) sbb:

$$
\log \left(K r l_{t}\right)=\alpha_{0}+\alpha_{1} \log (P D B r l)_{t}+\alpha_{2} r_{t}+\alpha_{3} \pi_{t}+\varepsilon_{t}
$$

di mana $\mathrm{Krl}$ adalah volume kredit berdasarkan total penggunaan yang diriilkan terhadap IHK, PDBrl adalah PDB riil yang diinterpolasikan menjadi data bulanan, $r_{t}$ adalah suku bunga kredit (sebagai proksi harga kredit), dan $p_{t}$ adalah inflasi tahunan atas dasar IHK.

\begin{tabular}{l|c|l|c}
\multicolumn{4}{c}{ Tabel 2. } \\
\multicolumn{1}{c}{ Variabel } & Sumber Data & \multicolumn{1}{c}{ Frekuensi } & Periode Observasi \\
Kredit Riil $(\mathrm{Krl})$ & DSM-BI & Bulanan & Jan 2003-Mar 2012 \\
\hline PDB Riil $(\mathrm{PDBrl})$ & DSM-BI & Bulanan di interpolasi & Jan 2003-Mar 2012 \\
\hline Inflasi $(\pi)$ & DSM-BI & Bulanan & Jan 2003-Mar 2012 \\
\hline Suku bunga kredit $(r)$ & DSM-BI & Bulanan & Jan 2003-Mar 2012
\end{tabular}

Parameter untuk variabel $\mathrm{PDBrl}$ diharapkan bernilai positif, dengan meningkatnya aktivitas perekonomian maka meningkat pula permintaan terhadap kredit. Nilai parameter untuk variabel $r$ diharapkan negatif, suku bunga kredit yang tinggi akan menurunkan permintaan terhadap kredit karena biaya atas dana meningkat. Parameter dari $\pi$ juga diharapkan bernilai negatif, senada dengan Eller et al (2010) hubungan negatif antara inflasi dan permintaan kredit dapat dilihat dari 2 aspek, pertama, saat inflasi telah menyentuh batas tertentu akan berasosiasi dengan volatilitas inflasi yang secara signifikan dapat mengganggu fungsi pasar keuangan dengan meningkatkan ketidakpastian. Kedua, jika suku bunga nominal tinggi, walaupun suku bunga riil rendah, pelaku ekonomi akan memilih kredit dengan durasi yang pendek, yang pada gilirannya membatasi volume kredit yang dipinjam.

\section{Persamaan Jangka Pendek Kredit}

Jika variabel-variabel pada persamaan (19) memiliki hubungan kointegrasi maka dapat dibangun persamaan dinamis jangka pendek sebagai persamaan error correction sbb:

$$
\Delta \log \left(K r l_{t}\right)=\beta_{0}+\beta_{1} \varepsilon_{t-1}+\beta_{2}{ }^{\prime} \Delta Z_{t}+\beta_{3} \Delta \log \left(K r l_{t-1}\right)+u_{t}
$$

di mana $\Delta \log (K r l)$ adalah pertumbuhan kredit riil, $\varepsilon_{t-1}$ adalah error correction term dari persamaan jangka panjang sebelumnya, $\beta_{1}$ adalah parameter error correction yang mengatur 
speed of adjustment kepada persamaan jangka panjang, dan $Z_{t}$ adalah himpunan variabel penjelas yang mungkin lainnya.

Vector $Z_{t}$ berisi determinan jangka pendek dari kredit yang terdiri dari sumber dana pihak ketiga serta risiko kredit. Dana pihak ketiga diharapkan memiliki hubungan positif karena dengan semakin meningkatnya dana yang tersedia maka meningkat pula kredit yang dapat disalurkan. Sedangkan untuk risiko kredit digunakan rasio Non Performing Loan (NPL) terhadap total aset. Hubungan yang diharapkan dari variabel ini adalah negatif karena semakin meningkatnya non performing loan maka keinginan bank memberikan kredit akan menurun.

Persamaan jangka pendek diatas berdasarkan asumsi bahwa proses adjustment terhadap ekuilibriumnya berada pada satu rejim. Asumsi ini dapat dilonggarkan dengan kerangka MS VECM dengan membiarkan parameter berubah menurut unobservable state nya. Dalam kerangka MS VECM maka persamaan jangka pendek diatas dapat diubah menjadi:

$$
\Delta \log \left(K r l_{t}\right)=\beta_{0 s t}+\beta_{1 s t} \varepsilon_{t-1}+\beta_{2 s t}{ }^{\prime} \Delta Z_{t}+\beta_{3 s t} \Delta \log \left(K r l_{t-l}\right)+u_{t}
$$

untuk setiap st $=1,2$, dst., dimana persamaan jangka pendeknya conditional terhadap variabel rejim yang unobservable $s_{t}$.

\section{HASIL DAN ANALISIS}

\subsection{Hasil HP Filter}

Hasil analisis menggunakan pendekatan HP Filter menunjukkan bahwa pertumbuhan kredit riil Indonesia saat ini masih berada pada kisaran trend jangka panjangnya baik menggunakan batas atas dan bawah 1 stdev ataupun standar IMF 1.75 stdev. Dapat dilihat bahwa pertumbuhan kredit riil hingga Mei 2012 sebesar 20,7\% masih dalam kisaran jangka panjang dan relatif lebih rendah dibanding pertumbuhan kredit dalam pada akhir 2008 yang

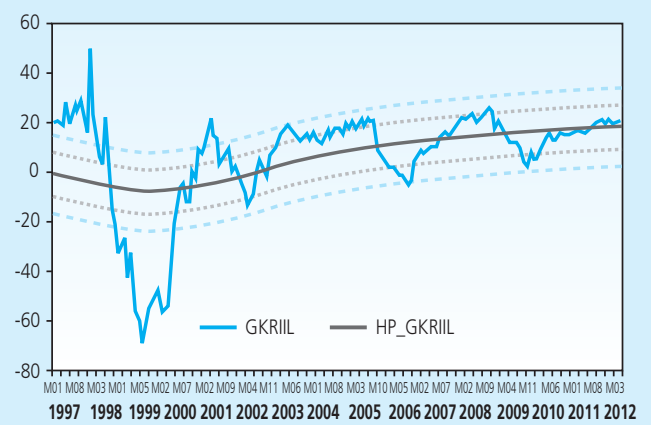

Grafik 4.

Trend Jangka Panjang Pertumbuhan Kredit Riil

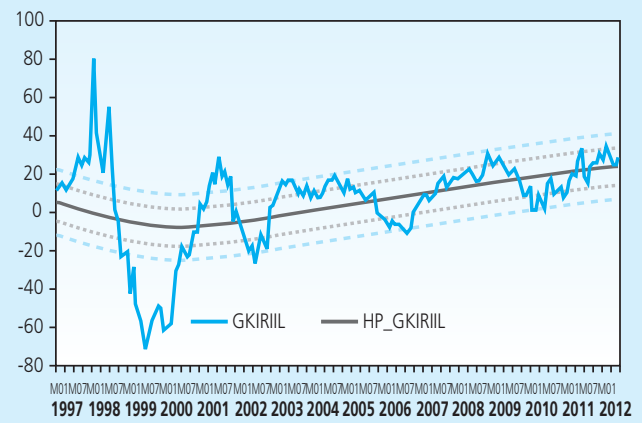

Grafik 5. Trend Jangka Panjang Kredit Investasi Riil 


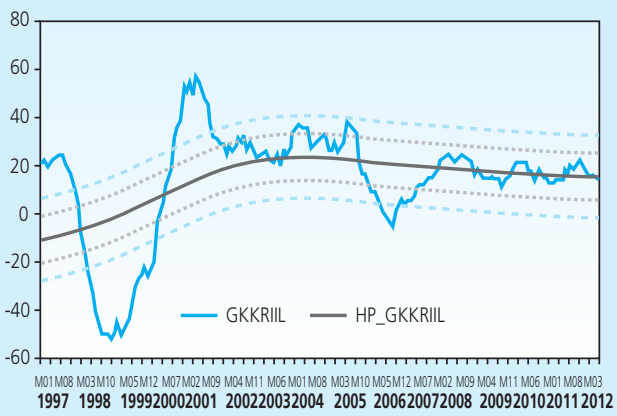

Grafik 6.

Trend Pertumbuhan Jangka Panjang Kredit Konsumsi Riil

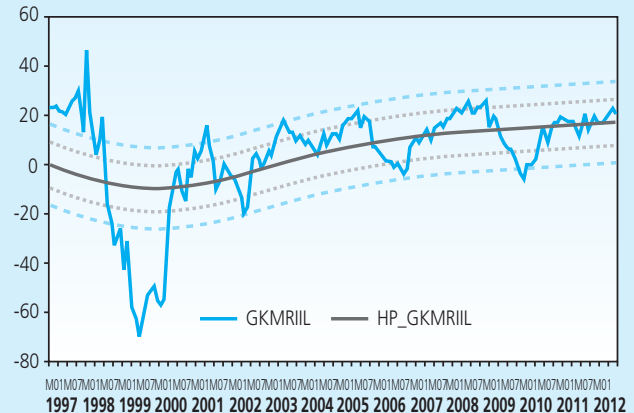

Grafik 7.

Trend Pertumbuhan Jangka Panjang Kredit Modal Kerja Riil

mendekati batas atas kisaran (Grafik 4). Bila dilihat dari disagregasinya, pertumbuhan kredit invetasi, kredit modal kerja dan kredit konsumsi juga masih berada pada trend jangka panjangnya (Grafik 5 s/d Grafik 7).

Namun demikian sebagaimana dikatakan oleh Cottarelli et al. (2005), salah satu kelemahan HP Filter yaitu mengukur trend dari keseluruhan observasi dan mengabaikan kemungkinan adanya structural break. Dengan pertimbangan tersebut, kami mencoba menghilangkan data selama krisis. Selanjutnya pengujian HP Filter dilakukan pada data selama periode Januari 2001 s.d Mei 2011.

Dengan memperhitungkan periode setelah krisis untuk memperoleh trend jangka panjang, terlihat bahwa pertumbuhan kredit riil secara total sudah mencapai batas atas jika menggunakan batasan 1 stdev, namun relatif masih terkendali jika menggunakan pendekatan 1,75 stdev

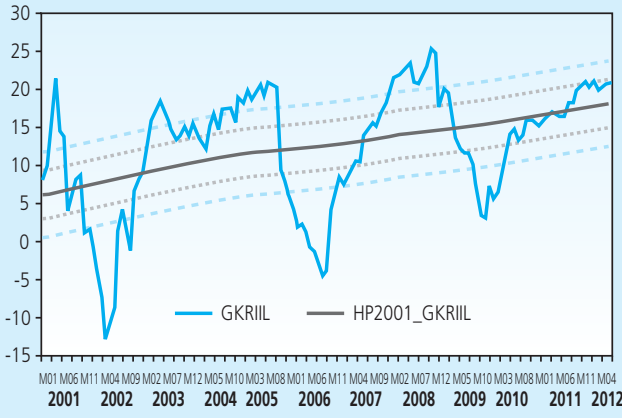

Grafik 8.

Trend Jangka Panjang Pertumbuhan Kredit Riil Sesudah Krisis

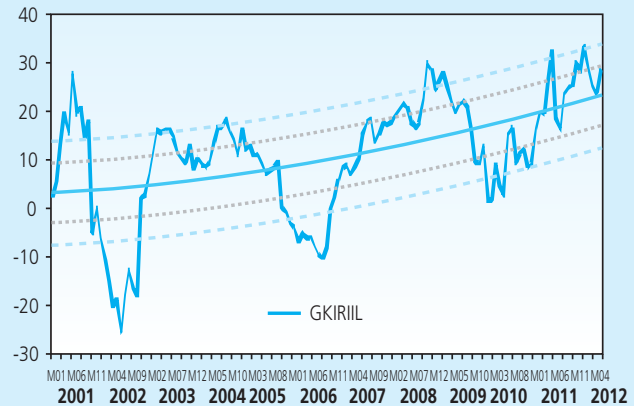

Grafik 9.

Trend Jangka Panjang Pertumbuhan Kredit Investasi Riil Sesudah Krisi 

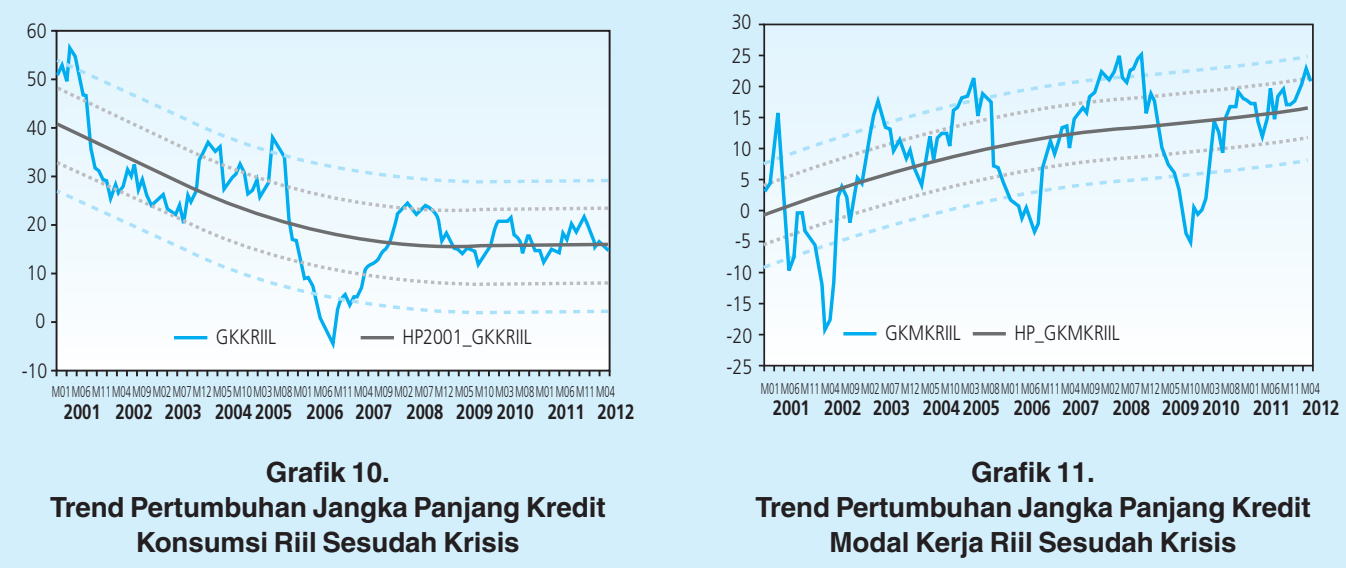

(Grafik 8). Pertumbuhan kredit yang sudah berada di batas atas jika menggunakan batasan 1 stdev adalah kredit modal kerja dan kredit investasi (Grafik 11 dan Grafik 10). Sementara itu kredit konsumsi masih berada dalam kisaran trend jangka panjangnya (Grafik 9).

Pendekatan lainnya untuk melihat adanya excessive credit growth adalah menggunakan trend jangka panjang dari rasio kredit total /PDB secara nominal. BCBS yang mengusulkan kebijakan countercyclical capital buffer menyatakan bawa penggunaan rasio kredit / PDB memiliki beberapa keuntungan dibandingkan pertumbuhan kredit ${ }^{6}$ yaitu : i) adanya hubungan yang kuat antara pertumbuhan kredit / PDB yang melebihi rata-rata jangka panjang dengan krisis perbankan, ii) dengan dinyatakan dalam rasio, maka variabel ini telah dinormalisasi dengan ukuran perekonomian, oleh karenanya rasio ini tidak terpengaruh oleh pola siklus permintaan kredit.

Dengan menggunakan data sesudah krisis, dari Grafik 12 terlihat bahwa rasio kredit terhadap PDB masih berada dalam kisaran trend jangka panjangnya walaupun cenderung berada di batas atas. Bila dibandingkan tahun-tahun sebelumnya, pertumbuhan proporsi kredit terhadap PDB terus meningkat sejak Desember 2009 hingga mencapai 29,7\% pada akhir triwulan 1-2012. Pergerakan rasio kredit modal kerja dan kredit investasi terhadap PDB cenderung lebih mudah mendekati batas atas dan batas bawah dari trend jangka panjang (Grafik 513 dan Grafik 5 15), tidak demikian halnya dengan kredit konsumsi yang cenderung lebih stabil (Grafik 5 14). Keadaan perekonomian nampaknya cukup besar mempengaruhi pergerakan rasio kredit modal kerja dan kredit investasi terhadap PDB.

6 Drehman, Borio, Gambacorta, Jimenez dan Trucharte (2010) "Countercylical Capital Buffer : Expoloring Options", BIS Working Paper No. 317. 


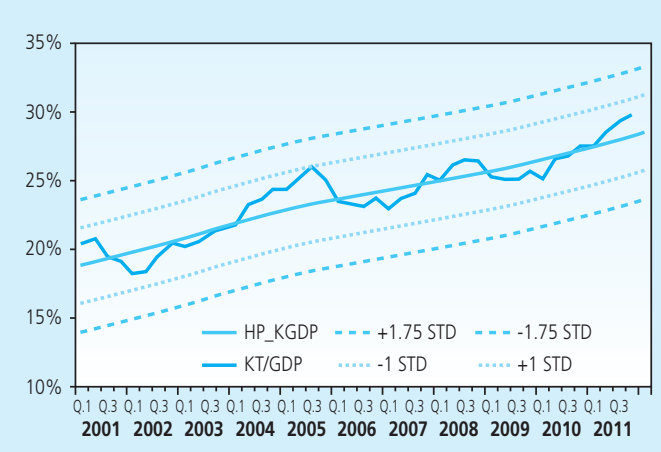

Grafik 12.

Trend Jangka Panjang Kredit/PDB Sesudah Krisis

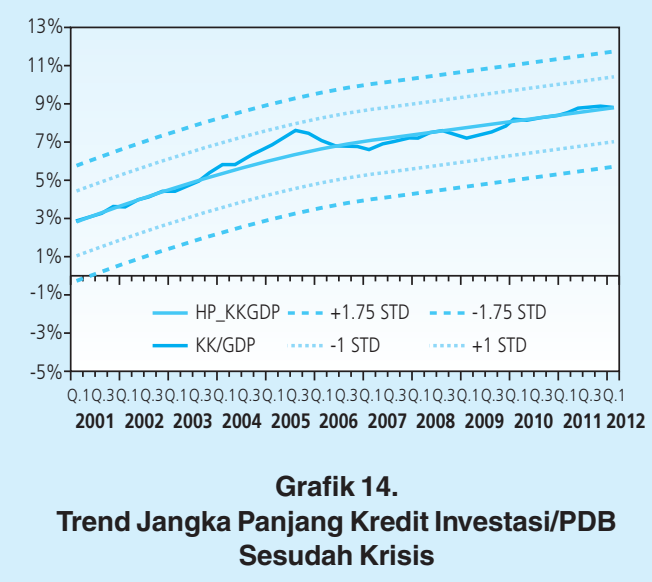

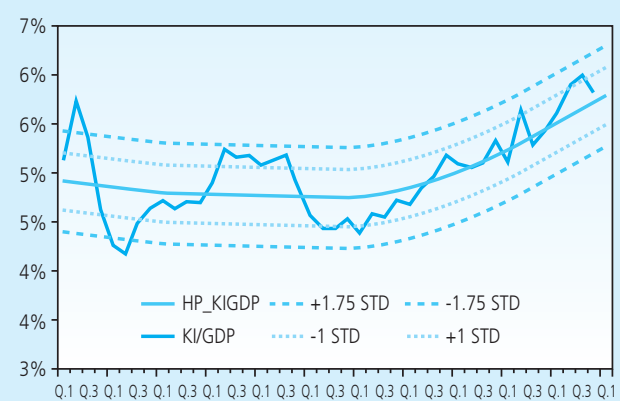

200120022003200420052006200720082009201020112012

Grafik 13.

Trend Jangka Panjang Kredit Investasi/PDB Sesudah Krisis

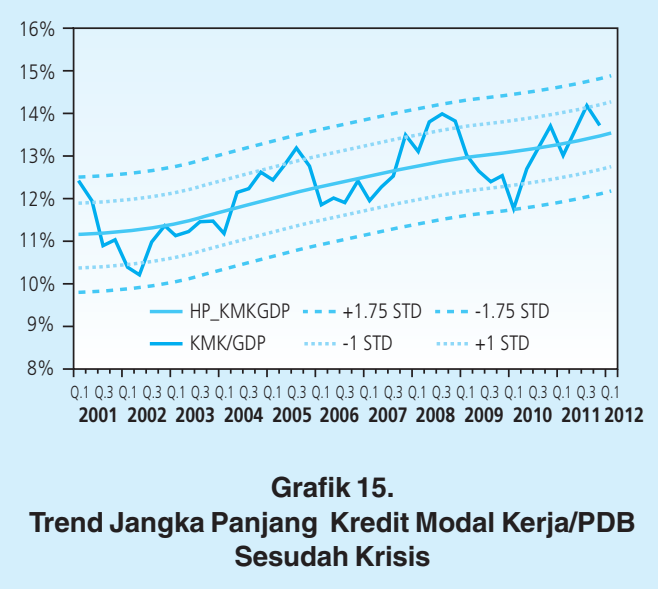

\subsubsection{Analisa Univariat Pertumbuhan Kredit Riil}

Analisa Markov Switching (MS) untuk data pertumbuhan kredit riil (univariat) menunjukkan bahwa pertumbuhan kredit riil (Januari 2003 s.d Maret 2012) dapat dimodelkan dengan MSI(3)AR(0), data time series dengan 3 rejim. Grafik 16 dan Tabel 3 s.d 4 berikut meringkas kronologis dari perubahan rejim pada kurun observasi. 


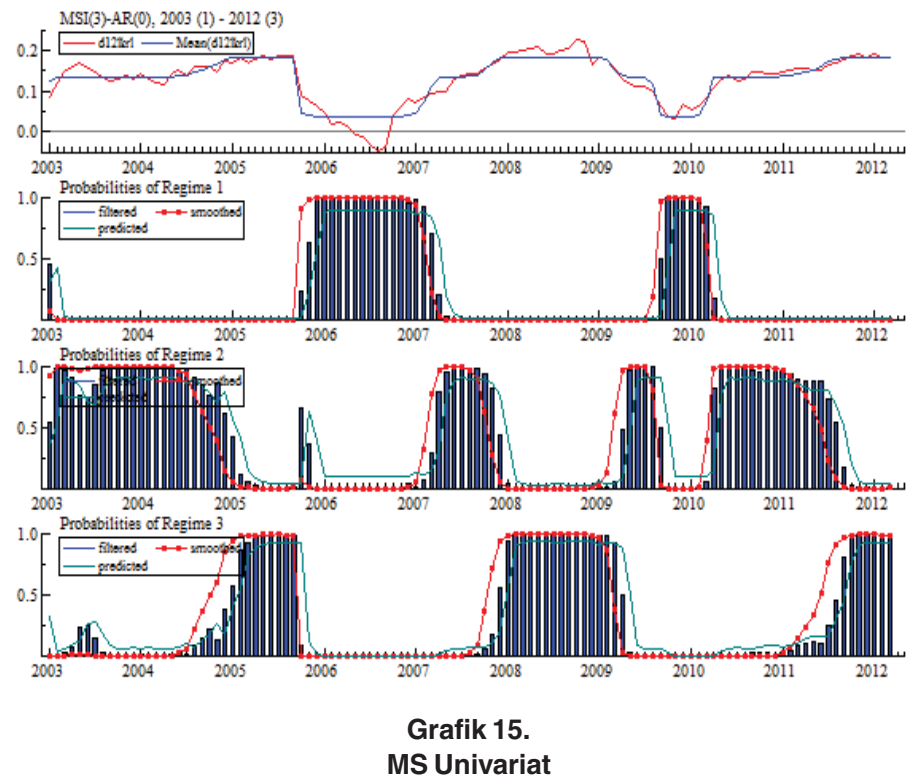

\begin{tabular}{l|l|l}
\multicolumn{1}{c}{ Rejim 1 } & \multicolumn{1}{c}{ Tabel 3. Rejim MS } \\
\hline $2005: 10-2007: 2$ & Rejim 2 & Rejim 3 \\
\hline $2009: 9-2010: 3$ & $2003: 1-2004: 9$ & $2004: 10-2005: 9$ \\
\hline & $2007: 3-2007: 10$ & $2007: 11-2009: 2$ \\
\hline & $2009: 3-2009: 8$ & $2011: 6-2012: 3$ \\
\hline Mean: 0.038 & $2010: 4-2011: 5$ & \\
\hline Stdev: 0.041 & & \\
\hline
\end{tabular}

Tabel 4. Spesifikasi Rezim

\section{Matriks Transisi Probabilitas}

\begin{tabular}{l|c|c|c} 
& Rezim 1 & Rezim 2 & Rezim 3 \\
Rezim 1 & 0.906 & 0.094 & 0.000 \\
\hline Rezim 2 & 0.023 & 0.915 & 0.062 \\
\hline Rezim 3 & 0.025 & 0.032 & 0.943
\end{tabular}

Predicted Regime Probabilities $(\mathrm{t}+1)$

\begin{tabular}{c|c|c} 
Regime 1 & Regime 2 & Regime 3 \\
0.000 & 0.0062 & 0.9938
\end{tabular}

\section{Statistik Rezim}

\begin{tabular}{l|r|c|c} 
& nObs & Prob & Duration \\
Regime 1 & 23.6 & 0.203 & 10.66 \\
\hline Regime 2 & 49.2 & 0.383 & 11.81 \\
\hline Regime 3 & 38.1 & 0.413 & 17.49
\end{tabular}

\section{Koefisien}

\begin{tabular}{l|c|c|c} 
& Mean & SE & T-val \\
Regime 1 & 0.038 & 0.0062 & 6.268 \\
\hline Regime 2 & 0.134 & 0.0048 & 28.261 \\
\hline Regime 3 & 0.183 & 0.0053 & 34.348
\end{tabular}


Rejim 3 merupakan rejim pertumbuhan kredit riil tinggi dengan mean pertumbuhan kredit sebesar $18.3 \%$. Rejim 2 merupakan rejim pertumbuhan kredit riil sedang dengan mean sebesar $13.4 \%$. Sedangkan rejim 1 merupakan rejim pertumbuhan kredit riil rendah dengan mean $3.8 \%$.

Dengan mengasumsikan bahwa pertumbuhan kredit riil pada rejim sedang (rejim 2) adalah pertumbuhan kredit riil yang moderat dan baik maka informasi statistik rejim 2 dapat dipergunakan sebagai informasi batas atas dan batas bawah pertumbuhan kredit riil. Berdasarkan statistik rejim 2 maka dapat dikatakan bahwa batas atas pertumbuhan kredit riil adalah $17.39 \%$ dan batas bawah 9.5\% $(\mu \pm 2 \sigma)$. Hasil MS menunjukkan bahwa probabilitas kredit untuk satu bulan kedepan masih berada di sekitar mean pertumbuhan kredit riil tinggi cukup besar, yakni sebesar $99.4 \%$.

\subsection{Analisa MS VECM}

Untuk mengidentifikasikan hubungan jangka panjang dari volume kredit maka dilakukan estimasi dari persamaan demand for credit. Penggunaan konsep ini diharapkan dapat memberikan gambaran mengenai excess credit yang mungkin terjadi. Berdasarkan penjelasan pada bab terdahulu, dilakukan pengujian secara ekonometrik yang meliputi stasionaritas, pengukuran lag optimal, uji residual, dan uji kointegrasi. Selanjutnya dilakukan estimasi VECM.

Uji akar unit dilakukan menggunakan uji Augmented-Dickey-Fuller (ADF) dan PhillipsPerron (PP) untuk hipotesis nul adanya unit root. Inspeksi visual terhadap variabel menunjukkan adanya perilaku trend pada volume kredit riil dan volume PDB riil, sedangkan pada inflasi dan suku bunga kredit tidak terdapat trend. Hasil uji stasioner sebagaimana pada Tabel 5 menunjukkan bahwa hampir seluruh variabel I(1) pada 5\% level dan stasioner dalam first differences.

Tabel 5. Uji Unit Root

\begin{tabular}{c|c|r|r|r|r|r|r} 
& \multicolumn{4}{|c|}{ Augmented Dickey-Fuller test statistic } & \multicolumn{3}{c}{ Phillips-Perron test statistic } \\
\cline { 2 - 8 } & Eksogen & Lag (SIC) & t-Stat & Prob. & Eksogen & Adj. t-Stat & Prob. \\
\hline $\log (K r l)$ & $\mathrm{C}, \mathrm{T}$ & 0 & -2.389 & 0.384 & $\mathrm{C}, \mathrm{T}$ & -2.453 & 0.351 \\
\hline$\Delta \log (K r l)$ & $\mathrm{N}$ & 5 & -2.205 & 0.027 & $\mathrm{~N}$ & -9.714 & 0.000 \\
\hline $\log (P D B r l)$ & $\mathrm{C}, \mathrm{T}$ & 10 & -1.913 & 0.643 & $\mathrm{C}, \mathrm{T}$ & -3.169 & 0.095 \\
\hline$\Delta \log (P D B r l)$ & $\mathrm{C}$ & 12 & -2.589 & 0.098 & $\mathrm{C}$ & -11.031 & 0.000 \\
\hline$r$ & $\mathrm{C}$ & 2 & -1.853 & 0.354 & $\mathrm{C}$ & -2.704 & 0.076 \\
\hline$\Delta r$ & $\mathrm{~N}$ & 0 & -3.125 & 0.0020 & $\mathrm{~N}$ & -10.102 & 0.000 \\
\hline$\pi$ & $\mathrm{C}$ & 1 & -2.343 & 0.1603 & $\mathrm{C}$ & -2.301 & 0.173 \\
\hline$\Delta \pi$ & $\mathrm{N}$ & 0 & -9.664 & 0.0000 & $\mathrm{~N}$ & -9.636379 & 0.0000
\end{tabular}


Setelah memastikan bahwa data yang akan digunakan dalam analisis bersifat stasioner di tingkat first difference, langkah berikutnya adalah menentukan panjang lag optimal dari persamaan VAR yang dibangun dari keempat variabel di atas. Jumlah lag optimal yang dipilih dilakukan dengan kriteria sebagaimana pada Lampiran. Kriteria Schwarz Information mengindikasikan 2 lag sementara Hannan-Quin Information mengindikasikan 4 lag, dan kriteria Akaike Information mengindikasikan 7 lag. Dari analisa terhadap residualnya, uji correlogram menunjukkan bahwa terdapat autokorelasi dari residual pada VAR dengan lag 2, sedangkan uji tersebut pada lag 4 tidak.7 Oleh karena itu pada penelitian ini dipilih lag optimal 4.

Dari uji kointegrasi dengan lag 4, Uji Trace mengindikasikan adanya 2 vektor kointegrasi, sementara uji $\lambda_{\max }$ (Lampiran) mengindikasikan adanya 1 vektor kointegrasi. Perbedaan yang muncul dari uji trace dan $\lambda_{\max }$ dapat disebabkan oleh permasalahan jumlah sampel yang terbatas atau model deterministik yang digunakan. Mempertimbangkan bahwa penelitian ini berfokus khusus untuk mempelajari mengenai kredit, maka kami menggunakan hasil uji $\lambda_{\max }$ dimana ada 1 vektor kointegrasi.

Vektor kointegrasi atau hasil estimasi VECM (dimana parameter Log(Krl) ditetapkan sama dengan 1) adalah sebagai berikut

\begin{tabular}{c|r|r|r}
\multicolumn{2}{c}{ Tabel 6. Vektor Kointegrasi } \\
Variabel & Koefisien & SE & T-Stat \\
\hline $\log (P D B r l)_{t-1}$ & -1.799 & 0.101 & $-17.869^{* * *}$ \\
\hline$r_{t-1}$ & 0.033 & 0.009 & $3.431^{* * *}$ \\
\hline$\pi_{t-1}$ & 0.019 & 0.004 & $4.818^{* * *}$ \\
\hline$E T C_{t-1}$ & -0.110 & 0.036 & $-3.087^{* * *}$ \\
\hline${ }^{* * *},{ }^{* *},{ }^{*}=$ signifikan pada alfa $=1 \%, 5 \%$, dan $10 \%$. & & \\
\hline
\end{tabular}

Parameter pada Grafik 6 menunjukkan tanda yang diharapkan. Dalam jangka panjang, permintaan kredit dipengaruhi secara positif oleh aktivitas perekonomian dan secara negatif oleh suku bunga kredit dan inflasi.

Penelitian ini selanjutnya melakukan uji weak exogeneity dari variabel-variabel yang ekuivalen dengan pengujian koefisien speed of adjustment dari variabel sama dengan nol. Dalam sistem terkointegrasi, jika variabel tidak merespon terhadap discrepancy dengan hubungan jangka panjangnya, maka variabel tersebut dapat dinyatakan weakly exogeneous. Artinya tidak ada informasi yang hilang jika variabel ini tidak dimodelkan dan variabel ini dapat masuk ke sisi sebelah kanan dari VECM tersebut.

7 Namun pada uji correlogram tersebut, autokorelasi tampak pada variabel PDBrl terhadap PDBrl lag 3, 6, dst. hal tersebut ditengarai akibat adanya interpolasi data PDBrl kuartalan menjadi data bulanan. 
Dari dapat dilihat sebagian koefisien speed of adjustment dari variabel-variabel tersebut bersifat weakly exogeneous.

\begin{tabular}{c|c|c|c}
\multicolumn{5}{c}{ Tabel 7. Speed of Adjustment ( od } \\
Variable & $\alpha$ & Standard error & t-statistic \\
\hline $\log (K r l)$ & -0.110 & 0.036 & -3.087 \\
\hline $\log (P D B r l)$ & 0.018 & 0.017 & 1.097 \\
\hline$r$ & 0.222 & 0.239 & 0.931 \\
\hline$\pi$ & -6.145 & 2.327 & -2.641 \\
\hline
\end{tabular}

Hasil ini setara dengan uji weak exogeneity ${ }^{8}$ untuk tiap variabel sebagaimana Tabel 8 di bawah ini:

\begin{tabular}{c|c|c}
\multicolumn{3}{|c}{ Tabel 8. } \\
Tes Statistik Weak Exogeneity \\
Variable & p-value & LR statistic \\
$\log (\mathrm{Kr} l)$ & 0.023 & 5.201 \\
\hline $\log (P D B r l)$ & 0.260 & 1.271 \\
\hline$r$ & 0.417 & 0.658 \\
\hline$\pi$ & 0.047 & 3.957
\end{tabular}

PDBrl dan $r$ merupakan variabel eksogen karena p-valuenya yang lebih besar dari level signifikansi 5\% namun tidak demikian untuk variabel permintaan kredit dan inflasi.

Pengujian terhadap hipotesis nol bahwa seluruh koefisien speed of adjustment kecuali untuk permintaan kredit adalah nol menghasilkan nilai p-value $=0.108$ dan LR stat 6.067. Hal ini berarti hipotesis nol tidak dapat ditolak dan dengan demikian variabel selain kredit dapat dinyatakan weakly exogenous dan tidak ada informasi yang hilang jika persamaan-persamaan tersebut tidak dimodelkan dan seluruh variabel tersebut dapat masuk ke sisi sebelah kanan dari VECM.

8 Dimana HO untuk uji ini adalah koefisien speed of adjustment pada persamaan short run dengan variabel dependennya adalah variabel terkait sama dengan nol. 
Hasil estimasierror correction model permintaan kredit dapat dinyatakan sebagai berikut:

\begin{tabular}{|c|c|c|c|}
\hline \multicolumn{4}{|c|}{ Tabel 9. Model VECM } \\
\hline Variabel & Koefisien & SE & T-Stat \\
\hline c & 0.008 & 0.002 & 3.290 *** \\
\hline$E C T_{t-1}$ & -0.110 & 0.004 & $-3.087^{* * *}$ \\
\hline$\Delta \log \left(K r l_{t-1}\right)$ & -0.058 & 0.078 & -0.748 \\
\hline$\Delta \log \left(K r l_{t-2}\right)$ & -0.201 & 0.078 & $-2.576^{* * *}$ \\
\hline$\Delta \log \left(K r l_{t-3}\right)$ & 0.093 & 0.078 & 1.182 \\
\hline$\Delta \log \left(P D B r l_{t-1}\right)$ & 0.218 & 0.169 & 1.283 \\
\hline$\Delta \log \left(P D B r l_{t-2}\right)$ & -0.498 & 0.179 & $-2.775 * * *$ \\
\hline$\Delta \log \left(P D B r l_{t-3}\right)$ & 0.912 & 0.172 & $5.312^{* * *}$ \\
\hline$\Delta \log \left(r_{t-1}\right)$ & -0.021 & 0.015 & -1.451 \\
\hline$\Delta \log \left(r_{t-2}\right)$ & 0.026 & 0.018 & 1.477 \\
\hline$\Delta \log \left(r_{t-3}\right)$ & 0.005 & 0.017 & 0.302 \\
\hline$\Delta \log \left(\pi_{t-1}\right)$ & 0.001 & 0.001 & -0.881 \\
\hline$\Delta \log \left(\pi_{t-2}\right)$ & -0.001 & 0.001 & -0.755 \\
\hline$\Delta \log \left(\pi_{t-3}\right)$ & 0.002 & 0.001 & 1.700 \\
\hline \multicolumn{4}{|c|}{${ }^{* * *},{ }^{* *},{ }^{*}=$ signifikan pada alfa $=1 \%, 5 \%$, dan $10 \%$} \\
\hline \multicolumn{4}{|c|}{$\begin{array}{l}\text { R-squared }=0.397 \\
\text { SE of regression=0.02 } \\
\text { F-stat }=5.93(0.00) \\
\text { Uji statistik yang ditampilkan meliputi goodness fit of the model, standard deviasi dari regresi dan uji } F \text { bahwa seluruh variabel } \\
\text { di sebelah kanan kecuali konstanta memiliki nilai nol }\end{array}$} \\
\hline
\end{tabular}

Koefisien dari error correction term adalah negatif dan signifikan. Hal ini mengindikasikan bahwa dalam hal terjadi ketidakseimbangan pada jangka pendek, maka akan terjadi penyesuaian ke hubungan jangka panjangnya. Hubungan kointegrasinya dapat dilihat pada Grafik 17 berikutyang menunjukkan bahwa vektor kointegrasi terlihat stasioner.

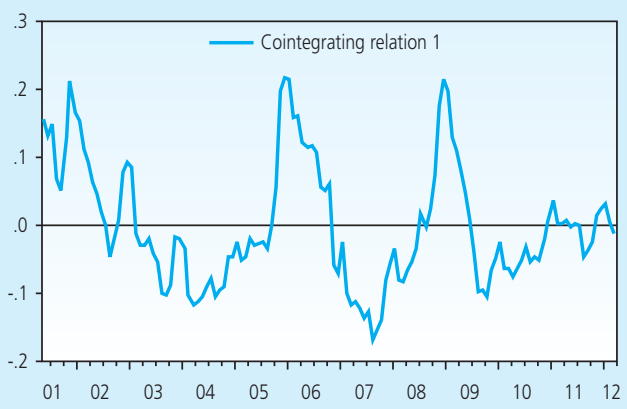

Grafik 17.

Kointegrasi 
Agar analisa dengan VECM ini dapat sejalan dengan analisa pada sub sebelumnya, maka perlu dilengkapi dengan analisa annual model dari kredit riil yakni $\Delta_{12} \log \left(\mathrm{Krl} \mathrm{l}_{\mathrm{t}}\right.$. Sesuai dengan Anglingkusumo (2005) hal tersebut dapat dilakukan dengan melakukan adjustment dari error correction term nya yakni dari $E C T_{\mathrm{t}-1}$ menjadi $E C T_{\mathrm{t}-13}$. Dengan memperhitungkan faktor supply for credit, maka dapat dibentuk persamaan $\Delta_{12} \log (\mathrm{Krl})$. sebagai berikut :

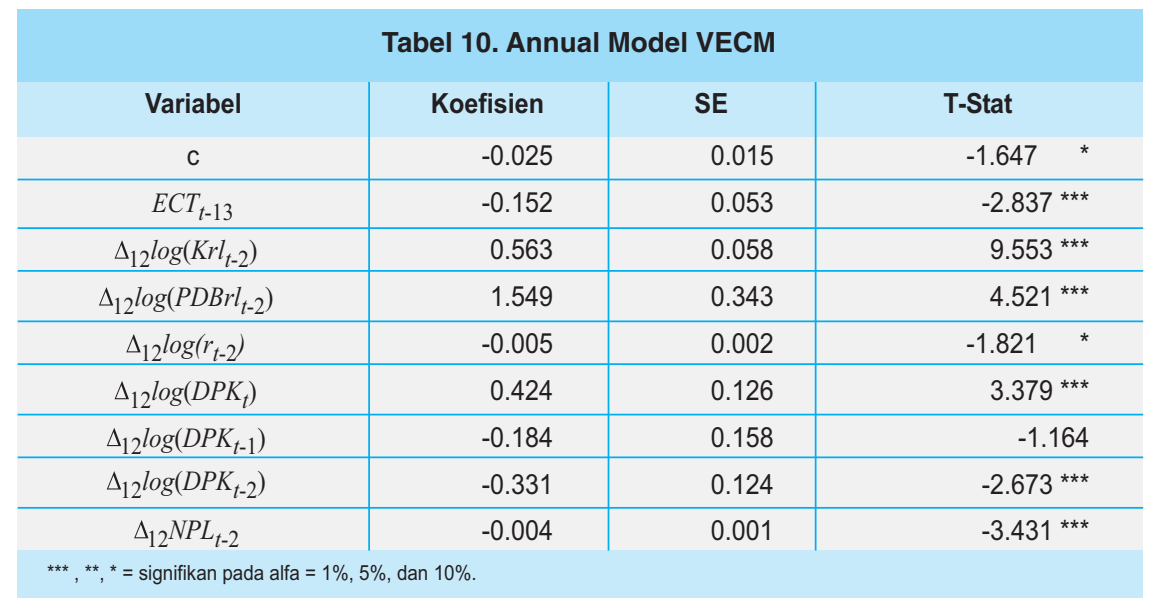

Parameter pada Tabel 10 di atas menunjukkan tanda yang diharapkan. Dalam jangka pendek pertumbuhan kredit dipengaruhi secara positif dan signifikan dari pertumbuhan kredit di masa lalu, pertumbuhan ekonomi dan pertumbuhan dana pihak ketiga. Sedangkan perubahan suku bunga kredit dan perubahan non performing loan berpengaruh secara negatif dan signifikan terhadap pertumbuhan kredit.

Analisa model linier dari $\Delta_{12} \log (\mathrm{Krl})$. diatas kemudian dilanjutkan dengan melakukan analisa MS dimana parameter dari masing-masing variabel dibiarkan berubah menurut unobservable state nya. Hasil analisa Markov Switching (MS) untuk pertumbuhan kredit riil dan faktor-faktor determinannya menunjukkan bahwa pertumbuhan kredit riil (Januari 2003 s.d Maret 2012) dapat dimodelkan dengan MSIA(3)ARX(0), data time series yang mengandung parameter autoregresive dengan 3 rejim. Rejim 1 merupakan rejim pertumbuhan kredit riil

\begin{tabular}{|c|c|c|c|c|c|c|c|c|c|}
\hline \multicolumn{10}{|c|}{ Tabel 11. Annual Model MSVECM } \\
\hline & c & $E C T_{t-13}$ & $\Delta_{12} \log \left(K r l_{t-2}\right)$ & $\Delta_{12} \log \left(P D B r l_{t-2}\right)$ & $\Delta_{12} \log \left(r_{t-2}\right)$ & $\Delta_{12} \log \left(D P K_{t}\right)$ & $\Delta_{12} \log \left(D P K_{t-1}\right)$ & $\Delta_{12} \log \left(D P K_{t-2}\right)$ & $\Delta_{12} N P L_{t-2}$ \\
\hline \multirow{2}{*}{$\begin{array}{c}\mathrm{R} \\
1\end{array}$} & 0.036 & -0.038 & 0.204 & -0.937 & -0.024 & 0.6211 & 0.018 & -0.115 & -0.009 \\
\hline & $0.159^{* * *}$ & 0.026 & $0.065^{* * *}$ & 0.398 ** & $0.003^{* * *}$ & $0.107^{* * *}$ & 0.160 & 0.116 & $0.001^{* * *}$ \\
\hline \multirow{2}{*}{$\begin{array}{l}\mathrm{R} \\
2\end{array}$} & 0.035 & -0.0544 & 0.496 & 1.352 & -0.002 & 0.176 & -0.1324 & -0.301 & 0.002 \\
\hline & $0.0139^{* *}$ & 0.034 & $0.050^{\star * *}$ & $0.239^{* * *}$ & 0.002 & $0.099 *$ & 0.138 & $0.109^{* \star *}$ & $0.001^{* * *}$ \\
\hline \multirow{2}{*}{$\begin{array}{l}\mathrm{R} \\
3\end{array}$} & 0.028 & -0.128 & 0.6225 & 0.4481 & 0.002 & -0.16 & 0.116 & 0.131 & -0.002 \\
\hline & 0.0223 & $0.042^{* \star *}$ & $0.113^{* * *}$ & 0.3361 & 0.004 & 0.107 & 0.095 & 0.093 & 0.002 \\
\hline
\end{tabular}


rendah dengan mean $8.1 \%$. Rejim 2 merupakan rejim pertumbuhan kredit riil sedang dengan mean sebesar $14.7 \%$. Sedangkan Rejim 3 merupakan rejim pertumbuhan kredit riil tinggi dengan mean pertumbuhan kredit sebesar $16.7 \%$.

Dari persamaan di atas terlihat bahwa pertumbuhan pdbriil, DPK, dan NPL mempengaruhi permintaan kredit pada saat berada di pertumbuhan rejim kredit rendah dan sedang. Pada rejim 3, yang mempengaruhi permintaan kredit hanya variabel jangka panjang dan pertumbuhan kredit di masa lalu. Variabel $E C T_{t-13}$ yang berpengaruh negatif signifikan hanya di rejim ketiga tersebut menunjukkan bahwa hubungan jangka panjang tidak patah.

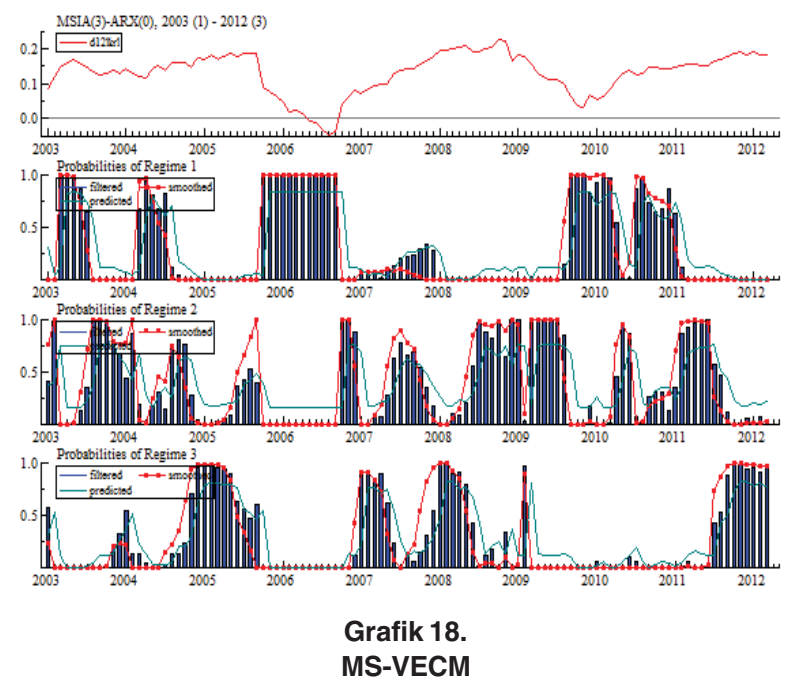

\begin{tabular}{|c|c|c|}
\hline \multicolumn{3}{|c}{ Tabel 12. rezim MSIA(3) ARX(0) } \\
\hline Rezim 1 & Rezim 2 & Rezim 3 \\
\hline $2003: 3-2003: 6$ & $2003: 1-2003: 2$ & $2004: 10-2005: 5$ \\
\hline $2004: 3-2004: 7$ & $2003: 7-2004: 2$ & $2007: 1-2007: 4$ \\
\hline $2005: 10-2006: 9$ & $2004: 8-2004: 9$ & $2007: 10-2008: 5$ \\
\hline $2009: 8-2010: 3$ & $2005: 6-2005: 9$ & $2009: 2-2009: 2$ \\
\hline $2010: 7-2010: 12$ & $2006: 10-2006: 12$ & $2011: 7-2012: 3$ \\
\hline & $2007: 5-2007: 9$ & \\
\hline & $2008: 6-2009: 1$ & \\
\hline & $2009: 3-2009: 7$ & \\
\hline & $2010: 4-2010: 6$ & \\
\hline & $2011: 1-2011: 6$ & Mean:0.167 \\
\hline Mean:0.081 & & Stdev:0.035 \\
\hline Stdev:0.063 & Mean:0.145 \\
\hline
\end{tabular}




\section{Tabel 13. Spesifikasi Rejim}

Matriks Transisi Probabilitas

\begin{tabular}{l|c|c|c} 
& Reg 1 & Reg 2 & \multicolumn{1}{|c}{ Reg 3 } \\
Reg 1 & 0.084 & 0.162 & 0.002 \\
\hline Reg 2 & 0.117 & 0.759 & 0.124 \\
\hline Reg 3 & 0.000 & 0.168 & 0.831
\end{tabular}

Predicted Regime Probabilities ( $\mathrm{t}+1)$

\section{Statistik Rejim}

\begin{tabular}{l|c|c|r} 
& nObs & Prob & \multicolumn{1}{|c}{ Duration } \\
Reg 1 & 33.7 & 0.289 & 6.11 \\
\hline Reg 2 & 45.9 & 0.407 & 4.15 \\
\hline Reg 3 & 31.4 & 0.303 & 5.93
\end{tabular}

\begin{tabular}{|c|r|r|}
\hline Regime 1 & Regime 2 & Regime 3 \\
0.0026 & 0.1804 & 0.817 \\
\hline
\end{tabular}

Dengan mengasumsikan bahwa pertumbuhan kredit riil pada rejim sedang (rejim 2) adalah pertumbuhan kredit riil yang moderat dan baik maka informasi statistik rejim 2 dapat dipergunakan sebagai informasi batas atas dan batas bawah pertumbuhan kredit riil. Berdasarkan statistik rejim 2 maka dapat dikatakan bahwa batas atas pertumbuhan kredit riil adalah $22.15 \%$ dan batas bawah $6.8 \%(\mu \pm 2 \sigma)$. Hasil MS menunjukkan bahwa probabilitas kredit untuk satu bulan kedepan masih berada di sekitar mean pertumbuhan kredit riil tinggi cukup besar, yakni sebesar $81.7 \%$.

\section{KESIMPULAN}

Penelitian ini memberikan 4 (empat) kesimpulan; pertama, secara umum berdasarkan pendekatan HP Filter selama periode Januari 1997 s.d Mei 2012, pertumbuhan kredit riil Indonesia beserta disagregasinya masih berada pada kisaran trend jangka panjangnya. Namun setelah periode krisis (Januari 2001 s.d Mei 2012) pertumbuhan kredit total, kredit modal kerja, dan kredit investasi menunjukkan telah melewati batas atas threshold 1 stdev dari trend jangka panjangnya. Untuk variabel rasio kredit terhadap PDB setelah krisis menunjukkan secara umum masih berada dalam kisaran trend jangka panjangnya walaupun untuk rasio kredit investasi terhadap PDB cenderung berada di batas atas. Kedua, analisa Markov Switching (MS) univariate menunjukkan bahwa pertumbuhan kredit riil dapat dimodelkan dengan 3 rejim (rendah, normal, tinggi). Batas atas pertumbuhan kredit riil untuk rejim normal adalah 17.39\%. Ketiga, terdapat hubungan kointegrasi antara kredit riil dengan PDB riil, inflasi serta suku bunga kredit. Dalam jangka panjang, permintaan kredit dipengaruhi secara positif oleh aktivitas perekonomian dan secara negatif oleh suku bunga kredit dan inflasi. Sementara dalam jangka pendek pertumbuhan kredit dipengaruhi rasio NPL dan dana pihak ketiga (DPK). Keempat, analisa Markov Switching VECM menunjukkan bahwa pertumbuhan kredit riil dapat dimodel kan dengan 3 rejim (rendah, normal, tinggi). Batas atas pertumbuhan kredit riil adalah $22.15 \%$. 
Penelitian dalam paper ini membuka ruang pengembangan lebih lanjut. Besaran threshold yang didapatkan dari hasil kajian ini sebatas sebagai indikator awal, diperlukan judgment dari otoritas kebijakan untuk menentukan besaran threshold kredit yang dianggap sudah berlebihan dengan mempertimbangkan indikator mikro perbankan lainnya dan faktor lainnya seperti alokasi kredit, konsentrasi kredit pada suatu sektor dsb. Terkait dengan model Markov Switching, dapat dipertimbangkan pengembangan selanjutnya dari penelitian ini yaitu dengan melakukan markov switching multivariate secara bersamaan antara variabel kredit dan variabel makroekonomi lainnya (seperti inflasi). 


\section{DAFTAR PUSTAKA}

Anglingkusumo, Reza (2005). "Money - Inflation Nexus in Indonesia: Evidence From a P-Star Analysis". Tinbergen Institute Discussion Paper. TI 2005-054/4. Vrije Universiteit Amsterdam

Bry, Gerhard dan Boschan, Charlotte (1971)."Cyclical Analysis of Time Series: Selected Procedures and Computer Programs". Technical Paper No. 20, National Bureau of Economic Research, New York.

Beck, T.,R. Levina and N. Loayza, 2000, "Finance and The Source of Growth", Journal of Finance and Economics, 58, p. 261-300.

Burns, Arthur dan Mitchell, Wesley (1946)."Measuring Business Cycles". National Bureau of Economic Research.

Boissay F., Calvo-Gonzales., Kozluk T. (2005), "Is Lending in Central and Eastern Europe Developing Too Fast ?", European Central Bank.

Cotarelly C., Dell' Ariccia G., Vladkova-Hollar I. (2005), "Early Birds, Late Risers and Sleeping Beauties: Bank Credit Growth to The Private Sector in Central and Eastern Europe and in the Balkans", Journal of Banking and Finance, 2009.

Den Heuvel, S. J. V. (2001). "The Bank Capital Channel of Monetary Policy, Mimeo. University of Penssylvania.

Eller, Markus., Frommer, Michael., Srzentic, Nora.,(2010) ,"Private Sector Credit in CESEE: Long-Run Relationships and Short-Run Dynamics"' Austrian Central Bank.

Frait, Jan., Gersl, Adam., Seidler, Jacub. "Credit Growth and Financial Stability in the Czech Republic", Policy Research Working Paper 5771, World Bank.

Furlong, Frederick T. (1992), "Capital Regulation and Bank Lending" Economic Review Federal Reserve Bank of San Fransisco

Dell'Ariccia, Giovanni et all (2012), "Policies for Macrofinancial Stability : How to Deal with Credit Booms", IMF Staff Discussion Note No. SDN/12/06.Policies

Gambacorta, Leonardo. \& Mistrully, Paolo E. , (2003)," Bank Capital and Lending Behaviour: Empirical Evidence for Italy". Bank of Italy

Gambacorta, Leondardo \& Ibanez, David M. (2011), "The Bank Lending Channel : Lessons from The Crisis." BIS Working Paper No. 345. 
Goldstein, M, (2001),"Global Financial Stability : Recent Achievements and Ongoing Challenges," Global Public Policies and Programs : Implications for Financing and Evaluation, Proceedings from a World Bank Workshop (Washington), pp. 157-61

Gourinchas p.O., Valdes R., Landerretche O. (2001). "Lending Booms : Latin America and the World", Working Paper 8249. National Bureau of Economic Research.

Iossifov, Plamen \& Khamis, May, 2009, "Credit Growth in Sub Saharan Africans : Sources, Risks and Policy Responses", IMF Working Paper WP/09/180.

International Monetary Fund (2004), "Are Credit Booms in Emerging Markets a Concern?" World Economic Outlook, April.

Jimenez,Gabriel., Steven, Ongena., José-Luis Peydró., and Saurina, Jesus., 2011, "Macroprudential Policy, Countercyclical Bank Capital Buffers and Credit Supply: Evidence from the Spanish Dynamic Provisioning Experiments," Working Paper Bank of Spain

Kraft, Evan, and Tomislav Galac, 2011, "Macroprudential Regulation of Credit Booms and Busts: the Case of Croatia," Policy Research Working Paper No. 5772 (Washington, DC: World Bank)

Krolzig, H.-M. (1997), "Markov Switching Vector Autoregressions: Modelling, Statistical Inference and Application to Business Cycle Analysis: Lecture Notes in Economics and Mathematical Systems", 454, Springer-Verlag, Berlin.

Krolzig, H.-M.(1998), "Econometric Modeling of Markov-Switching Vector Autoregressions Using MSVAR for Ox", Discussion Paper, Department of Economics, University of Oxford.

Lim, C , Columba, A et all (2011), "Macroprudential Policy : What Instruments and How to Use Them?" IMF Working Paper No.WP/11/238.

Guonan, Ma., Xiandong, Yan., dan Xi, Liu (2011)." China's Evolving Reserve Requirement", BIS Working Paper No. 360

Martin, Antoine., Mc Andrews, James, \& Skeie, David., "A Note on Bank Lending in Times of Large Bank Reserves", Federal Reserve Bank of New York Staff Reports, May 2011.

Mendoza, Enrique G., \& Terrones, Marco E. "An Anatomy of Credit Booms : Evidence from Macro Aggregates and Micro Data", NBER Working Paper 14049

Niemira, Michael P. Dan Klein, Philip A. (1994). "Forecasting Financial and Economic Cycles", John Wiley \& Sons, Inc, USA.Oxford.

Psaradakis, Z.,M. Sola and F. Spagnolo, 2004. "On Markov Error Correction Models, with an Application to Stock Prices and Dividends", Journal of Applied Econometrics 19(1). 69-88. 
Rajan, R.G. and Zingales L. 2001. "Financial Systems, Industrial Structure and Growth". Toward operationalizing macroprudential policy ;When to Act, Oxford Review of Economic Policy. 17(4) p. 461-482

Reinhart, Carmen M., and Kenneth S. Rogoff, 2009, "The Aftermath of Financial Crises,"NBER Working Paper No. 14656.

Tabak, Benyamin M., Noronha, Ana C. \& Cajueiro, Daniel, 2011 "Bank Capital buffer, Lending Growth and Economic cyle : Empirical Evidence for Brazil", Central Bank of Brazil.

Tovar, Camilo., Garcia-Escribano, Mercedes., dan Martin, Mercedes V. (2012), "Credit Growth and the Effectiveness of ReserveRequirements and Other Macroprudentiallnstruments in Latin America", IMF Working Paper No. WP/12/142. 


\section{LAMPIRAN}

\section{Lag Length Criteria}

VAR Lag Order Selection Criteria

Endogenous variables: LOG(KRIIL) LOG(PDBRL) IKWA INFY

Exogenous variables: $\mathrm{C}$

Date: 08/13/12 Time: $12: 18$

Sample: 2001M01 2012M03

Included observations: 127

\begin{tabular}{c|c|c|c|c|c|c} 
Lag & LogL & LR & FPE & AIC & SC & HQ \\
\hline 0 & -269.2697 & NA & 0.000869 & 4.303459 & 4.393040 & 4.339855 \\
\hline 1 & 620.0215 & 1708.559 & $9.26 \mathrm{e}-10$ & -9.449157 & -9.001253 & -9.267179 \\
\hline 2 & 676.6073 & 105.1516 & $4.89 \mathrm{e}-10$ & -10.08830 & $-9.282077^{*}$ & -9.760744 \\
\hline 3 & 693.9919 & 31.21011 & $4.79 \mathrm{e}-10$ & -10.11011 & -8.945559 & -9.636966 \\
\hline 4 & 729.3157 & 61.19088 & $3.55 \mathrm{e}-10$ & -10.41442 & -8.891549 & $-9.795696^{*}$ \\
\hline 5 & 746.9960 & 29.51363 & $3.48 \mathrm{e}-10$ & -10.44088 & -8.559688 & -9.676576 \\
\hline 6 & 756.8198 & 15.77990 & $3.86 \mathrm{e}-10$ & -10.34362 & -8.104101 & -9.433730 \\
\hline 7 & 788.8405 & $49.41785^{*}$ & $3.04 \mathrm{e}-10 *$ & $-10.59591^{*}$ & -7.998074 & -9.540443 \\
\hline 8 & 801.2941 & 18.43513 & $3.26 \mathrm{e}-10$ & -10.54006 & -7.583901 & -9.339011 \\
\hline
\end{tabular}

\section{Correlogram}

\section{Autocorrelations with 2 Std.Err. Bounds}

$\operatorname{Cor}($ LOG(KRIIL),LOG(KRIIL)(-i))

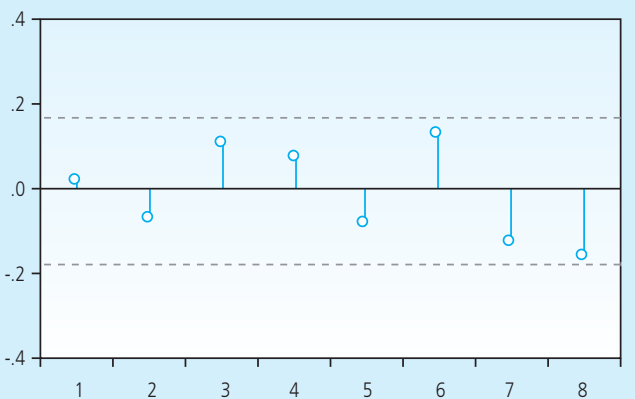

$\operatorname{Cor}($ LOG(KRIIL),LOG(PDBRL)(-i))

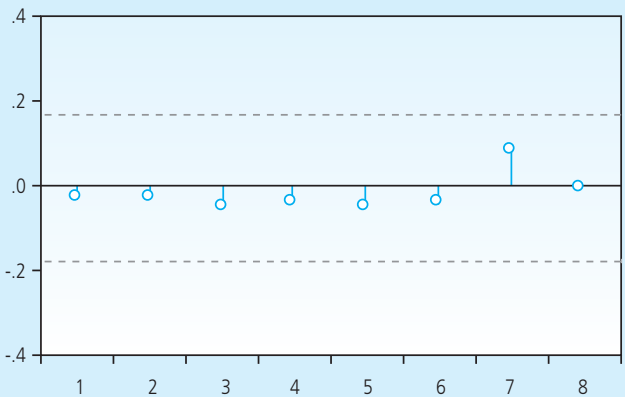



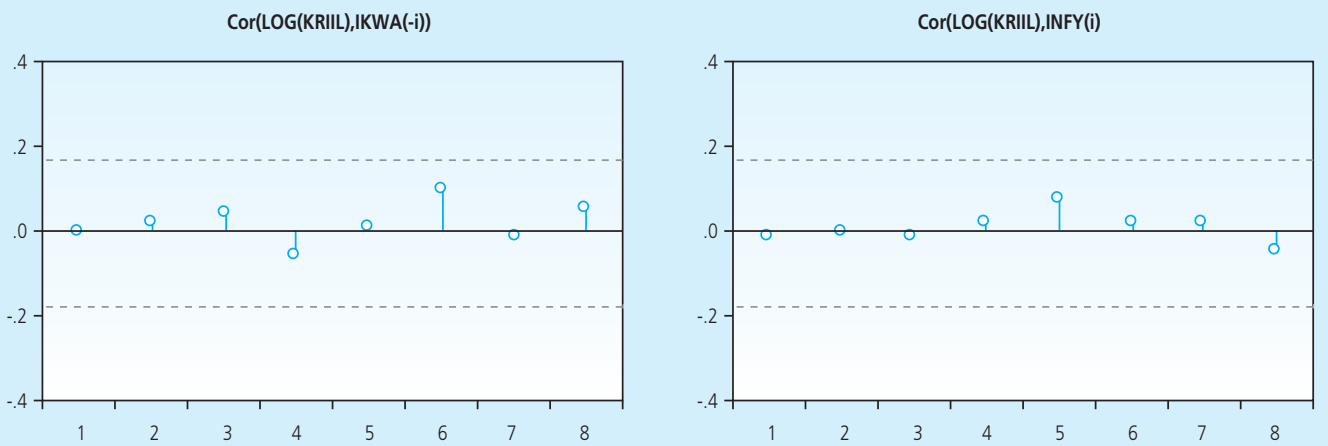

Cor(LOG(PDBRL),LOG(KRI)(-i))

Cor(LOG(PDBRL),LOG(PDBRL)(-i))
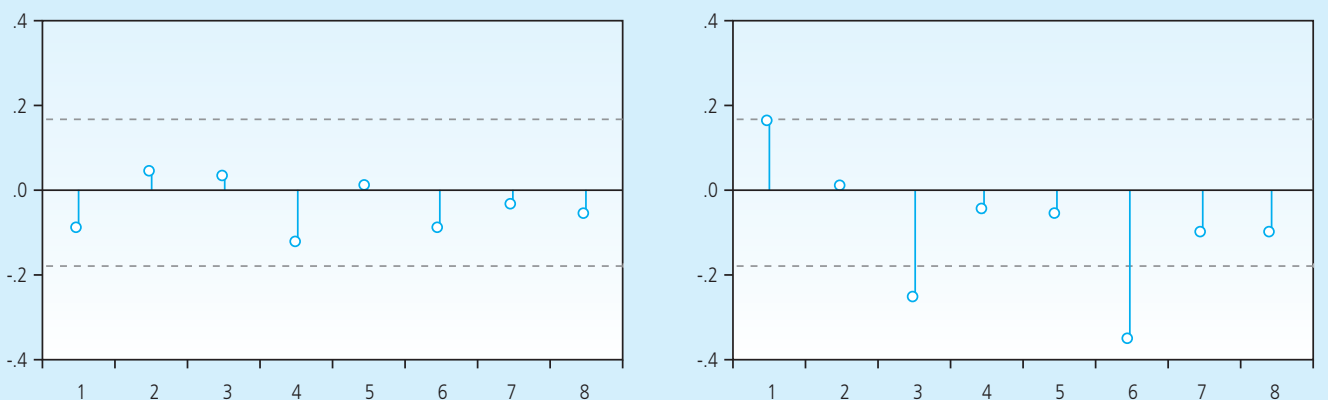

$\operatorname{Cor}(\operatorname{LOG}($ PDBRL),IKWA(-i))

Cor(LOG(PDBRL),INFY(-i))
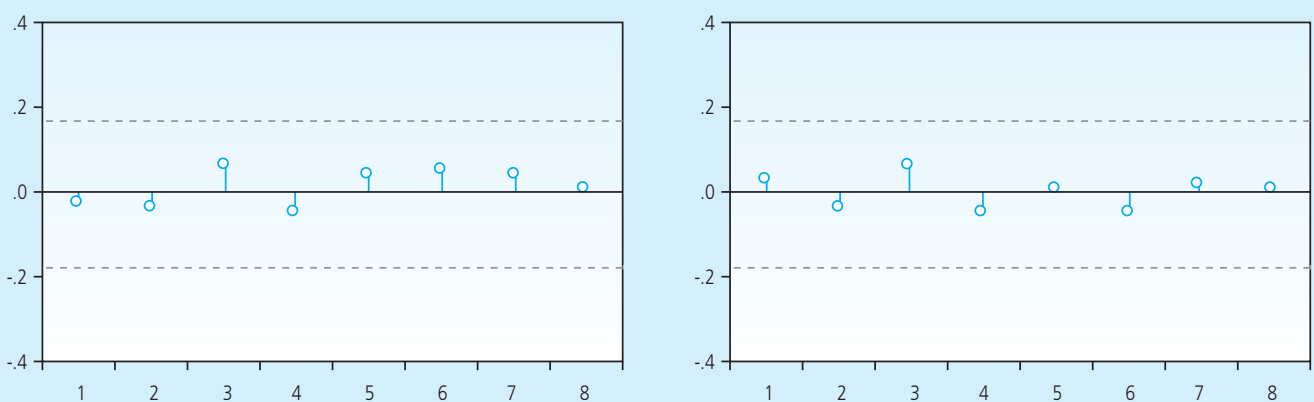

Cor(IKWA,LOG(KRIIL)(-i))

Cor(IKWA,LOG(PDBRL)(-i))
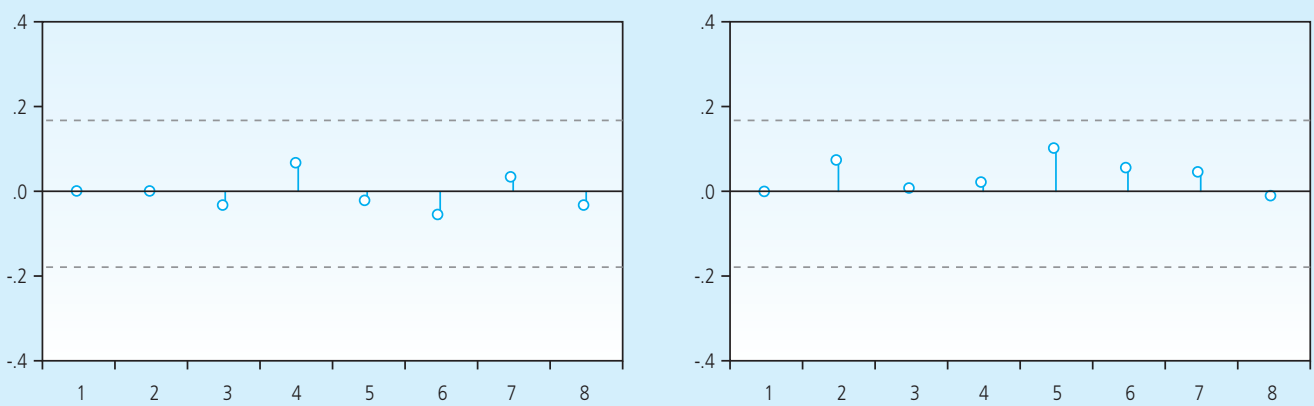

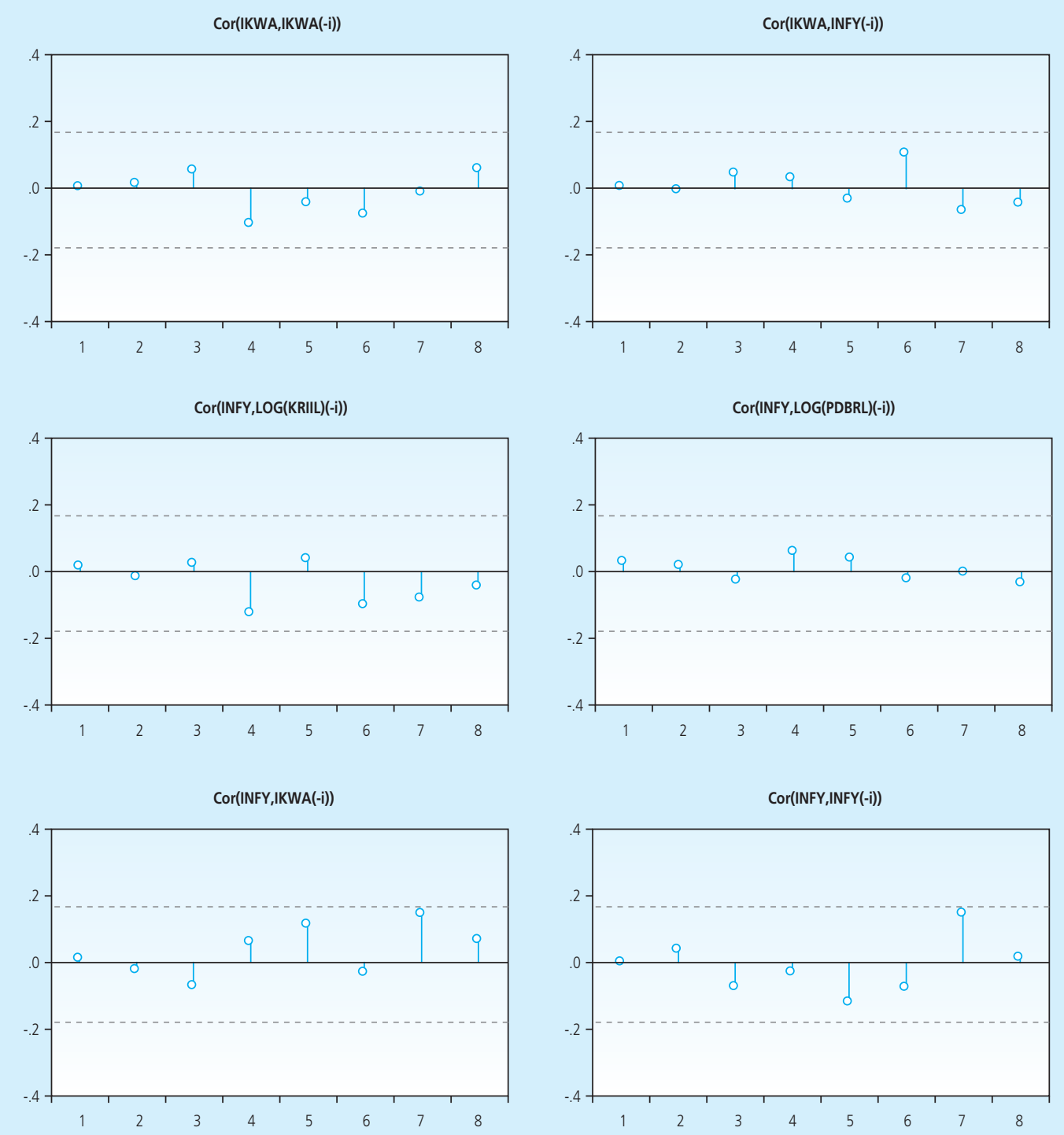


\section{Cointegration Test}

\begin{tabular}{|c|c|c|c|c|}
\hline Hypothesized & & Trace & 0.05 & \\
\hline No. of CE(s) & Eigenvalue & Statistic & Critical Value & Prob. ${ }^{* *}$ \\
\hline None * 0.263464 & 70.59464 & 47.85613 & 0.0001 & \\
\hline At most 1 * & 0.123531 & 30.84096 & 29.79707 & 0.0378 \\
\hline At most 2 & 0.095145 & 13.69994 & 15.49471 & 0.0915 \\
\hline At most 3 & 0.005389 & 0.702520 & 3.841466 & 0.4019 \\
\hline
\end{tabular}

\begin{tabular}{|c|c|c|c|c|}
\hline Hypothesized & & Max-Eigen & 0.05 & \\
\hline No. of CE(s) & Eigenvalue & Statistic & Critical Value & Prob. ${ }^{* *}$ \\
\hline None * 0.263464 & 39.75368 & 27.58434 & 0.0009 & \\
\hline At most 1 & 0.123531 & 17.14102 & 21.13162 & 0.1654 \\
\hline At most 2 & 0.095145 & 12.99742 & 14.26460 & 0.0785 \\
\hline At most 3 & 0.005389 & 0.702520 & 3.841466 & 0.4019 \\
\hline
\end{tabular}

